IZA DP No. 10225

Prevalence of Long Hours and Skilled Women's Occupational Choices

Patricia Cortés

Jessica Pan

September 2016 


\title{
Prevalence of Long Hours and Skilled Women's Occupational Choices
}

\author{
Patricia Cortés \\ Questrom School of Business, Boston University \\ Jessica Pan \\ National University of Singapore \\ and IZA
}

Discussion Paper No. 10225

September 2016

\author{
IZA \\ P.O. Box 7240 \\ 53072 Bonn \\ Germany \\ Phone: +49-228-3894-0 \\ Fax: +49-228-3894-180 \\ E-mail: iza@iza.org
}

Any opinions expressed here are those of the author(s) and not those of IZA. Research published in this series may include views on policy, but the institute itself takes no institutional policy positions. The IZA research network is committed to the IZA Guiding Principles of Research Integrity.

The Institute for the Study of Labor (IZA) in Bonn is a local and virtual international research center and a place of communication between science, politics and business. IZA is an independent nonprofit organization supported by Deutsche Post Foundation. The center is associated with the University of Bonn and offers a stimulating research environment through its international network, workshops and conferences, data service, project support, research visits and doctoral program. IZA engages in (i) original and internationally competitive research in all fields of labor economics, (ii) development of policy concepts, and (iii) dissemination of research results and concepts to the interested public.

IZA Discussion Papers often represent preliminary work and are circulated to encourage discussion. Citation of such a paper should account for its provisional character. A revised version may be available directly from the author. 
IZA Discussion Paper No. 10225

September 2016

\section{ABSTRACT \\ Prevalence of Long Hours and Skilled Women's Occupational Choices*}

Gender differences in occupations account for a sizable portion of the persistent gender pay gap. This paper examines the relationship between the demand for long hours of work (as proxied for by the share of men working 50 or more hours per week) and skilled women's occupational choice. Exploiting variation across 215 occupations and four decades in the US, we find that the prevalence of overwork in an occupation significantly lowers the share of college educated young married women with children working in that occupation. These findings are robust to controlling for the occupational distribution of similarly aged males and married women with no children, suggesting that the prevalence of overwork reduces the desirability of the work environment for women with family responsibilities and is not merely proxying for other demand side shocks. Similar results are obtained using a panel of European countries.

JEL Classification: J16, J24, J22

Keywords: long hours, overwork, occupational choice, gender

Corresponding author:

Jessica Pan

Department of Economics

National University of Singapore

1 Arts Link

Singapore 117570

Singapore

E-mail: jesspan@nus.edu.sg

\footnotetext{
* We are grateful to seminar participants at the Department of Labor, the Royal Economic Society, the 2016 SOLE Meetings, and the 2016 ASSA Meetings for numerous helpful comments and suggestions. The research in this paper was supported by a grant from the U.S. Department of Labor.
} 


\section{Introduction}

Despite large gains in the economic status of women over the past few decades, gender gaps in earnings, labor force participation and career advancement continue to persist in many developed countries (Blau 2012, Blau and Kahn, 2006). As women close the gap in human capital investments, gender differences in occupation and industry are emerging as increasingly important determinants of the gender pay gap. Blau and Kahn (2016) document that in 2010, occupational differences account for about a third of the gender wage gap and is, by far, the largest observed component.

But why are the occupational distributions of males and females still so different? One explanation that has received increasing attention, both in the popular press and in the recent academic discourse, is the role of occupational characteristics such as workplace flexibility and workplace "culture" in explaining persistent gender gaps in job choice, advancement opportunities, and earnings, particularly among highly-skilled women. Long hours of work and inflexible working conditions have been cited as important drivers for the lack of women in STEM industries (Fouad et al, 2012, Snyder, 2014) and the corporate sector (Goldin and Katz, 2011, Goldin, 2014).

For reasons that we will explore in this paper, even when employed full-time, women continue to shoulder a disproportionate burden of household responsibilities (Bianchi et al., 2000, Stone, 2007). For example, calculations from the Multinational Time-Use Survey (MTUS) reveal that, across nine developed countries, including the US, women who work full-time spend about one to two hours more each day on household production as compared to male full-time workers. ${ }^{1}$ These constraints may be even more binding for skilled women although college-educated women put in more time in the labor market, they spend increasingly more time with their children relative to their less educated counterparts (Guryan,

\footnotetext{
${ }^{1}$ Refer to Appendix Table 1.
} 
Hurst, and Kearney, 2008). Higher household responsibilities presumably make women less able or willing to accommodate increasing workplace demands for their time.

A related development is that workplace time demands appear to be rising in the US. As illustrated in Figure 1, and documented by Kuhn and Lozano (2008), there has been a large increase in the share of men working long hours (defined as working 50 or more hours per week) over the past few decades, particularly among the college-educated. The surge in overwork prevalence has been so large for the college educated, that in 1940 it was the group with the lowest incidence of males working 50+ hours per week, whereas today it is the group with the highest incidence of overwork by a large margin. Confirming these trends, Aguiar and Hurst (2007) document growing inequality in leisure - post-1985, less-educated adults experienced significantly larger gains in leisure relative to those with a college education or more. While the prevalence of overwork has declined in the last decade - likely as a result of the great recession - the share of educated males working long hours in the US remains very high, especially when compared to other developed countries. For example, in 2010, the share of college educated males working $50+$ hours per week in the US was $36 \%$, larger than that in every Western European country, including France (31\%), United Kingdom (28\%), Germany (26\%), Italy (22\%), Spain (17\%), and the Netherlands (10\%). ${ }^{2}$

In this paper, we systematically explore the relationship between the prevalence of overwork and women's occupational choice. More specifically, we test if women respond to greater time demands in an occupation by switching to more family-friendly occupations or by exiting the labor force. Our focus is on the occupational choices of skilled women (specifically, those with college degree or more). There are several reasons for this - first, as depicted in Figure 1, the increase in the prevalence of long hours has been concentrated among skilled workers. Second, we anticipate that work hours considerations are likely to

\footnotetext{
${ }^{2}$ Own calculations using the US Census and the EU-LFS.
} 
be more relevant to skilled women relative to their unskilled counterparts as skilled women are less likely to be constrained in terms of job mobility. Skilled women are more likely to be able to afford to exit the labor market or to switch to more flexible, but potentially lower paying occupations. ${ }^{3,4}$ Finally, an important advantage of focusing on a narrow skill group is that we are able to compare the occupational choices of similarly skilled women (and men) across occupations with similar skill demands. ${ }^{5}$

To help interpret our empirical results, we begin by presenting a simple model of household time allocation and occupational choice that illustrates the conditions under which an increase in the prevalence of overwork affects the labor supply decisions and occupation choices of workers and how this effect varies by gender and marital status. Our model, which abstracts from leisure for simplicity, assumes that workers choose between occupations that differ in terms of their hours requirements. We show that women are likely to switch to a job with fewer hours or to drop out of the labor force in response to an increase in the hours required by the woman's job in two distinct cases. The first is when men and women have the same preferences, are equally productive in household production, and the wife's wage is lower than that of her husband's. In this case, a household is better off if the woman switches to a job with fewer hours or exits the labor force than by absorbing the cost of a reduction in the production of the household good. The second is when the wife has higher earnings potential than her husband, but either she is more productive than her husband at home, or her preferences regarding the value of market work and the value of the household public good are different from her husband's. These differences in preferences could arise because of

\footnotetext{
${ }^{3}$ For example, Flabbi and Moro (2012) estimate a search model and document that women with a college degree value work-hours flexibility more than women with a high school degree.

${ }^{4}$ For completeness, we conducted the main analysis for the sample of lower skilled workers (defined as those with less than a college degree). In general, we do not find any evidence of a systematic relationship between the prevalence of overwork and the occupational choice of non-college educated women in both the US data and the cross-country data. These results are available on request.

${ }^{5}$ In addition, our analysis using college major information in the ACS can only be conducted on individuals with at least a college degree.
} 
social norms regarding gender roles in the household and women's role in childrearing (e.g. Akerlof and Kranton, 2000). In the empirical section, we provide some suggestive evidence that both channels are in effect.

Our empirical analysis consists of two exercises that exploit variation across occupations and over time in the prevalence of overwork. The first exercise focuses on the US and uses Census and ACS data. For the second exercise, we use a panel of 11 Western European countries and utilize cross-country variation as an additional source of variation to identify the effects of interest. The main outcome in our analysis is the occupational distribution of a given demographic group, measured as the share of of a given population that is working in a particular occupation. This outcome variable captures individuals who have switched occupations as well as those who have exited the labor force. We consider demographic groups defined on the basis of gender, marital status, and children - which serve as proxies for the cost of providing long hours of work. Our main group of interest is married women aged 25-40 with children, which we expect to be the most affected by changes in the prevalence of overwork in their occupation. We relate the occupational distribution of this group to the share of males working 50 or more hours in each occupation, controlling for occupation and year fixed effects. ${ }^{6}$ To address the possibility that occupation-specific demand shocks are correlated with the prevalence of overwork and may exert an independent effect on the occupational choice of females, we control for the occupational distribution of other subgroups (males, single females and married females with no children) of the same age range who are likely to be less sensitive to increases in the demand for overtime work but whose occupational decisions are likely to respond to occupation-specific demand shocks. We also present "placebo" tests showing that the prevalence of overwork appears to have effects mainly on the occupational distribution of women with the most household responsibilities.

\footnotetext{
${ }^{6}$ In our cross-country exercise, we also include in the econometric specifications country fixed effects and all two-way fixed effects interactions.
} 
Finally, to address the possibility of reverse causation, in particular, the concern that a large share of married women with children in an occupation might drive changes in occupational flexibility, we present dynamic specifications with a lead of our key independent variable of interest.

Using variation across 215 occupations over four decades in the US, and a fixed effects approach to isolate variation within occupations over time, we find that the prevalence of overwork in an occupation negatively impacts the share of married mothers aged 25 to 40 who choose to work in that occupation. The results are robust to controlling for the occupation distribution of males of the same age range, as well as married women without children, who presumably do not differ much in terms of skills and preferences as married women with children, but differ in terms of their preferences for flexibility. In addition, placebo tests confirm that young mothers are the only demographic group for which we find large and statistically significant negative effects of the prevalence of overwork on occupational choice. When we augment the baseline model with a lead of the prevalence of overwork, we find that the lead is generally small and not statistically significant, whereas the contemporaneous effect maintains its significance and magnitude, suggesting that changes in the prevalence of overwork are a cause rather than an effect of the observed changes in the occupational distribution of young mothers. The magnitude of our preferred estimates suggest that a one standard deviation increase in the prevalence of overwork reduces the share of married mothers choosing to work in that occupation by close to 0.2 of a standard deviation.

For the second empirical exercise, we add cross-country variation to our analysis. We use data from the European Union Labor Force Survey (EU-LFS) for 11 Western industrialized countries from 1998 to 2010. Similar to our analysis using US data, we estimate fixed effects models, but use a different source of variation, namely, variation at the country by occupation-group by year level, to identify the effects. To ensure sufficient number of 
observations for each unit of analysis, occupations are aggregated into 20 occupation groups. There are two advantages of this exercise. First, it allows us to control for occupationspecific shocks that are common to all countries that might have an independent effect on women's occupational choices. Second, the results from this exercise serve as a useful robustness test of the US analysis, and provide us with some degree of confidence that our results are generalizable across countries. The results from the cross-country exercise are relatively similar to those obtained based on the US analysis. We find a negative and statistically significant effect of the prevalence of overwork on the occupational decisions of young mothers, and not much of an effect for the other demographic groups. The magnitude of the effect obtained using the cross-country panel is about 40 to 60 percent smaller than that for the US; this is likely explained by the broader occupational classifications used as well as the shorter time frame of the cross-country analysis.

Having shown that the prevalence of overwork is significantly related to the occupation choices of skilled young mothers, we examine why the observed effects are concentrated among this group. The empirical tests we consider draw on the implications of the simple household model that we develop. We divide mothers (and fathers) in the sample into two groups - those who are expected (based on demographics) to earn more than their husbands (wives), and those who are expected to earn less than their husbands (wives). Using the US panel data, we find that the prevalence of long hours has an effect on the occupational choice of young skilled mothers, even for those who have a higher potential wage than their husbands. This finding suggests that women have different preferences and/or productivity in the household sector. We also find an effect for fathers, but only if they are expected to earn less than their wives, suggesting that the more straightforward channel of optimal household time allocation also plays a role.

We complement the panel analysis with a cross-section of college majors (instead of oc- 
cupations) from the 2009 to 2014 ACS, which allows us to more finely test the predictions of the model and to directly measure potential effects on labor force participation. We find that an increase in the prevalence of overwork in a college major has a large effect on the likelihood of young skilled mothers with that major dropping out of the labor force, even for mothers who have a higher potential wage than their husbands. Nonetheless, these effects appear to be smaller for women who are expected to earn more than their husbands, suggesting that the two channels are in effect. In addition, we find statistically significant, albeit smaller, effects of the prevalence of overwork on husbands' labor force participation when husbands' expected earnings fall short of their wives'. Conversely, when husbands are expected to out-earn their wives, we do not find any significant effect of the prevalence of overwork on husbands' participation in the labor force. Furthermore, using the ACS data, we show that the results are unlikely to be explained by assortative matching, as the results are robust to restricting the sample to couples in which the spouses have different majors.

Although it is widely accepted that women, particularly those with young children, place a higher value on non-market time and have greater demand for workplace flexibility and shorter work hours (Flabbi and Moro, 2012, Lim, 2015, Wiswall and Zafar, 2016), the empirical literature on the relationship between long work hours, participation decisions, and occupational choice is more limited. Using longitudinal data from the SIPP, Cha (2013) shows that mothers are more likely to exit male-dominated occupations when they work 50 hours or more per week, but the same effect is not observed for men or childless women. Using register data from Denmark, Pertold-Gebicka, Pertold, and Gupta (2016) find that women switch from the private sector to the more family friendly public sector after the birth of their first child. Herr and Wolfram (2012) document that among Harvard graduates, women in flexible jobs - defined as the capacity to cut one's hours - are five to six percentage points more likely to remain working after having children. Wasserman (2015) focuses on the 
decisions of female medical residents and shows that a reduction in weekly residency hours of medical specialties induced women to enter those specialties. Our empirical question is similar to Wasserman (2015), with a broader focus on the effects of the prevalence of long work hours on the extensive margin of participation, as well as on the occupational choices of high-skilled women more generally.

This paper also complements the recent literature that explores the relationship between the returns to working long hours and the gender pay gap. Goldin (2014) documents that occupations vary in terms of how they reward long hours of work and occupations characterized by a higher degree of convexity in the relationship between earnings and weekly hours are also those with the largest gender wage gaps. Cha and Weeden (2014) document that rising returns to overwork, coupled with the gender gap in the propensity to work overtime, worked to slow the convergence of the gender wage gap between 1979-2009, particularly in management occupations. Cortes and Pan (2016) find that supply-side shocks induced by low-skill immigration enable women to put in longer hours of work, helping them to close the gender wage gap in occupations with high returns to flexibility. This paper focuses on a different dimension of flexibility - the prevalence of overwork - and examines its effects on the occupational distribution and labor force participation decisions of females.

The rest of the paper is organized as follows. Section 2 presents a simple model of household time allocation and occupational choice. Section 3 describes the data and presents the empirical analysis using US data. Section 4 discusses the data and empirical application based on the panel of European countries. Section 5 concludes. 


\section{Theoretical Framework}

In this section, we discuss the theoretical underpinnings of how an increase in the prevalence of overwork might affect a worker's labor supply and occupational choice, and how this effect is expected to vary by gender and marital status.

In our simple model, the utility of an individual depends on the consumption of a market good, their partner's consumption (if married), and a public good (for example, children). For simplicity, we do not formally include leisure in this model. ${ }^{7}$ More specifically, individual $i$ 's utility when married to individual $j$, is given by:

$$
U_{i}\left(l_{i}, l_{j}\right)=\delta_{i} * w_{i} * l_{i}+w_{j} * l_{j}+\beta_{i} * \ln \left(\alpha_{i}\left(1-l_{i}\right)+\alpha_{j}\left(1-l_{j}\right)\right)
$$

where $l_{i}$ is the labor supply of individual $i$ and $0 \leq l_{i} \leq 1, w_{i}$ is wage per unit of labor, $\delta_{i}$ and $\beta_{i}$ are preference parameters, and $\alpha_{i}$ is productivity in the production of the household good.

This general specification covers both unitary and non-unitary household models.

\section{$2.1 \quad$ Unitary Model}

Under the unitary household model, each spouse places the same weight on their own consumption and their partner's consumption, as well as on the household public good $\left(\beta_{i}=\beta_{j}\right.$ and $\delta_{i}=\delta_{j}=1$ ). In this case, utility depends linearly on household consumption of the market good, and the household good is produced using a linear production function, where spouses are perfect substitutes in household production, but differ in terms of their marginal productivities. For now, we assume that workers can freely choose their hours and that males $(m)$ and females $(f)$ are equally productive in household production $\left(\alpha_{i}=\alpha_{j}\right)$. In

\footnotetext{
${ }^{7}$ We will discuss the implications of including leisure in the model later in this section.
} 
this setting, the optimal labor supplies of the husband and the wife will depend on who has a higher market wage.

Case 1: $w_{m}>w_{f}$. Assuming that $w_{m}>\beta$, men devote all their time to working in the market $\left(l_{m}=1\right)$. Wife's labor supply will depend on her wage relative to $\beta$. In the case where $w_{f}>\beta$, the wife devotes some of her time to market work, with $l_{f}^{*}=1-\frac{\beta}{w_{f}}$. If $w_{f}<\beta$, the wife spends all her time in household production. Note that if we believe that $\beta$ is zero or very small for single individuals, a single woman will work full-time, similar to her male counterpart. A married woman will work more than a single woman, but less than a mother, if we assume that $\beta$ is larger when one has children.

Next, we consider the case where hours are not as flexible. In particular, we assume that there are only two types of jobs (or occupations) - one that requires long hours $(\bar{l}<1)$ and one that requires short hours $(\underline{l}<\bar{l}<1)$. We assume that both jobs pay the same hourly wage, but we allow the wage to differ by gender. We begin with the case in which $\bar{l}<1$ in order to consider some comparative statics.

As long as $w_{m}>\beta$ it is optimal for the male to work as long as possible i.e. $l_{m}=\bar{l}$. If women could freely choose their hours of work, their optimal labor supply would be: $l_{f}^{*}=2-\frac{\beta}{w_{f}}-\bar{l}$. If, however, hours are not flexible, she would compare the utility of the various options. In particular, we have the following cases:

1. If $l^{*}=0$, she will devote all her time to household production

2. If $l^{*}>\bar{l}$, she will take the long hours job

3. If $\bar{l}>l^{*}>\underline{l}$, she will choose the short hours job if $w_{f}(\bar{l}-\underline{l})<\beta * \ln \left[\frac{(1-l)+\left(1-l^{m}\right)}{(1-\bar{l})+\left(1-l^{m}\right)}\right]$, and the long hours job otherwise. Notice that women are more likely to prefer the short hours job the lower the female wage $w_{f}$, the higher the $\beta$, and the longer her husband works. 
4. If $\underline{l}>l^{*}>0$, she will not to work if $w_{f} \underline{l}<\beta * \ln \left[\frac{2-l^{m}}{(1-\bar{l})+\left(1-l^{m}\right)}\right]$, and work in the job with short hours otherwise. She is likely to opt out of the labor market if $w_{f}$ is low, $\beta$ is higher, and the more hours her husband works.

Suppose there is an increase in the hours requirement of the long hours job $(\bar{l})$. In terms of our empirical exercise, this would correspond to an increase in the prevalence of overwork in the long hours job. An increase in $\bar{l}$ would tend to affect women's job choices in cases 2 and 3, making it more likely that a woman would choose to switch to the job with shorter hours. $^{8}$ If prior to the change, the woman was already staying at home full-time or working in the short hours job, she will not be affected by an increase in $\bar{l}$.

Case 2: $w_{f}>w_{m}$. Now, we turn to the case where female wages are higher than male wages. This case is particularly relevant for high-skilled women who may be married to men with lower earnings potential. ${ }^{9}$

If $w_{f}>\beta$, then the roles in the previous analysis are switched and the wife will always choose the long hours job, even if the hours requirement of the long hours job were to increase. In this case, we should not observe women switching jobs or dropping out of the labor force in response to an increase in $\bar{l} .^{10}$

In this situation, women are likely to change their job choices or labor supply decisions in response to an increase in the hours requirement in the long hours job only if we assume that men and women have different productivities in household production. In particular, if women are more productive in the production of the household good $\left(\alpha_{f}>\alpha_{m}\right)$, the husband will work longer hours, even if the woman's wage is higher, when $\frac{w_{f}}{\alpha_{f}} \leqslant \frac{w_{m}}{\alpha_{m}}$.

\footnotetext{
${ }^{8}$ Note that if there is a wage penalty for working fewer hours (part-time), then it might be optimal for the woman to switch from the long hours job to dropping out of the labor force.

${ }^{9} 43 \%$ of college-educated women in our sample are married to males with less education than themselves.

${ }^{10} \mathrm{We}$ do not consider the case in which even for the member with the highest wage, $w<\beta$. In this case, if $2 w<\beta$, both members will choose to stay at home full-time. If $2 w>\beta$, the lowest wage member will stay at home, and the one with the highest wage will work part-time in the market. Neither situation is commonly observed in the data.
} 


\section{$2.2 \quad$ Non-cooperative Model}

Next, we turn to the case where men and women have different preferences and interact in a non-cooperative way. Specifically, we allow men and women to place different weights on the household good ( $\beta$ 's) and their spouses' labor income ( $\delta$ 's).

Each spouse solves the following optimization problem (assuming $\alpha_{m}=\alpha_{f}$ ), taking $l_{j}$ as given:

$$
\max _{l_{i}} U_{i}\left(l_{i}, l_{j}\right)=\delta_{i} *\left(w_{i} * l_{i}\right)+w_{j} * l_{j}+\beta_{i} * \ln \left(\left(1-l_{i}\right)+\left(1-l_{j}\right)\right)
$$

Now, what matters for who will optimally work more hours is the ratio $\frac{\beta}{\delta w}-$ whichever spouse has the lower ratio will work longer hours. ${ }^{11}$ Assuming that at least one of the spouses works full time, the analysis follows the unitary model, where the spouse with the highest $\frac{\beta}{\delta w}$ ratio will work in the market if $w_{i}>\frac{\beta_{i}}{\delta_{i}}$, and his/her labor supply will be given by $l_{i}^{*}=1-\frac{\beta_{i}}{\delta_{i} w_{i}}$. If workers cannot flexibly choose their hours, the spouse with the lower $\frac{\beta}{\delta w}$ will take the job with long hours and the other spouse will compare her options, just as in the unitary model.

\subsection{Summary of Model Predictions}

In sum, our model suggests that compared to men, women are more likely to switch jobs or exit the labor force after an increase in the hours requirement of the long hours job if the following conditions hold:

1. Both husband and wives have the same preferences and productivities at home, and women's wages are high enough such that they are working positive hours in the market, but face a wage that is lower than that of their husband's (i.e. $\beta<w_{f}<w_{m}$ ).

\footnotetext{
${ }^{11}$ Throughout we assume that for both spouses, $\frac{\beta}{\delta w}<2$, so that least one of them will work in the market.
} 
2. Women face higher wages than males, but they are either more productive at home $\left(\alpha_{f}>\alpha_{m}\right)$, they value the household good more than their husbands $\left(\beta_{f}>\beta_{m}\right)$, or they suffer a utility penalty from working in the market $\left(\delta_{f}<\delta_{m}\right)$.

Why would women be more productive at home, value the household good more than males, or suffer a greater utility penalty from working in the market? One explanation might come from social norms regarding the appropriate role of women in the household. For example, men/women may place a lower value on women's labor market income since a working wife might challenge conventional gender roles (Akerlof and Kranton, 2000). Men may also face a higher cost of engaging in household production because it goes against their identity as breadwinners in the household. Furthermore, women may also place a higher value on the household good (e.g. "better kids" or a cleaner house) relative to men because it is how they are judged by society.

\section{Assortative Matching}

A potential confounding factor affecting the analysis in our empirical application is that the increase in the prevalence in overwork for the women's job or occupation, might be correlated with the prevalence of overwork in her husband's job if there is assortative matching. As suggested by the model, an increase in the husband's hours of work will reduce women's hours worked in the market to compensate for the decrease in the production of the household good. In a model with leisure, an increase in the husband's labor supply may also decrease women's labor supply through an income effect. In the empirical analysis, we will provide some suggestive evidence that assortative matching does not appear to be driving our main results. 


\section{Empirical Evidence from the US}

\subsection{Data and Descriptive Statistics}

We use data from the 1980, 1990, and 2000 Census, and the three-year 2012 American Community Survey (ACS). ${ }^{12}$ The sample is limited to native-born individuals with at least a college degree and the unit of observation is an occupation in a given decade. Our analysis focuses on 215 occupations that are consistently defined over the sample time period. ${ }^{13} \mathrm{We}$ define overwork as working 50+ hours a week and construct the prevalence of long work hours in an occupation as the share of overwork among males age 25 to $54 .{ }^{14}$

There is significant variation across occupations in the prevalence of overwork. For example, in 2010, the top three occupations - physicians, chief executives, and lawyers, had a prevalence of long hours higher than 60 percent. On the other hand, the incidence of long work hours for librarians, government and social workers, and pharmacists was less than 15 percent. The average for engineers and architects is close to 30 percent, below the average of 37 percent. There is also significant variation across occupations in the changes in the prevalence of overwork over time. On average, prevalence increased by 10 percentage points between 1980 and 2010. However, some occupations experienced large positive changes for example, chief executives experienced the largest increase in the incidence of long work hours (33 percentage point), while the increase was larger than 15 percentage points for most engineers, economists, lawyers, and financial specialists. In contrast, a number of other occupations such as pharmacists, veterinarians, health therapists, and technicians, saw a

\footnotetext{
${ }^{12}$ In the text, tables and figures, we refer to the data from the 2012 ACS as corresponding to the 2010 time period.

${ }^{13}$ We use the crosswalk developed by Dorn (2009) to construct the 215 consistently defined occupations. We drop occupation codes that indicate that occupations are in a "not elsewhere classified" category since these categories tend to combine a number of different occupations that may be changing over time. These comprise 19 occupations in our sample. The list of 215 occupations used in the analysis is presented in Appendix Table 2.

${ }^{14}$ Appendix Table 3 reports the descriptive statistics for the occupation-level dataset.
} 
decline of more than 10 percentage points in the prevalence of long work hours.

As discussed by Goldin (2014), workplace flexibility is a multi-dimensional concept that encompasses the number of hours to be worked, particular hours worked, as well as other factors such as the mode and frequency of interactions with clients and colleagues. For our analysis, we use the prevalence of overwork as a proxy for workplace flexibility for ease of measurement and interpretation. While our focus on the prevalence of overwork is admittedly narrow, using time-use surveys, we find evidence that this measure is highly correlated with other indicators of workplace flexibility such as the probability of working on weekends and non-standard hours (e.g. early in the morning or late at night on weekdays). First, we observe similar trends by education in the share of full-time male workers who report working on weekends - constructed using the AHTUS-X. Second, pooling together the 2003 to 2012 ATUS surveys, we find large and statistically significant correlations between the share of males working long hours and the probabilities of working on the weekends or during nonregular times across broad occupation groups. ${ }^{15}$ We do not use these alternative measures of workplace flexibility in the main analysis largely due to sample size considerations - the ATUS is considerably smaller than the US Census and is a lot less suited for analysis at the occupation level.

The key dependent variable in our analysis is the occupational distribution of females of a given demographic group, measured as the share of females in a demographic group working in a given occupation in each decade. Therefore, a decline in the share of women working in a particular occupation incorporates individuals who have switched occupations as well as those who have exited the labor force. Demographic groups are characterized by age, marital status, and fertility - variables used as proxies for the cost of providing long hours.

\footnotetext{
${ }^{15}$ These analyses are available on request.
} 


\subsection{Empirical Analysis}

\subsubsection{Graphical Evidence using Cross-Sectional Variation across Occupations}

Before turning to the formal empirical analysis, we begin by presenting some descriptive evidence using cross-occupation data from 1980 to 2010 that illustrates the relationship between the occupation distribution of highly skilled females and the fraction of males working long hours in that occupation. As shown in Figure 2, there is a clear negative association between the gender gap (female-male) in employment share and the prevalence of overwork in an occupation in each decade. Occupations with a higher share of males working $50+$ hours a week have a lower fraction of females employed in that occupation, relative to males. Appendix Table 4 reports the regression coefficients corresponding to the bivariate correlations shown in Figure 2 for the full sample of occupations in each period as well as excluding the two outlier occupations with the largest employment share of females relative to males (primary school teachers and nurses). In all the specifications, the relationship between the prevalence of overwork and the female-male difference in employment shares at the occupational level is negative and statistically significant.

\subsubsection{Evidence from Panel Data}

While the cross-occupation correlations are suggestive of a negative relationship between the prevalence of overwork in an occupation and occupational choice, one might be concerned that unobserved differences across occupations could be driving the observed correlations. Therefore, for our main analysis, we exploit variation across occupations and over time in the prevalence of overwork. As observed in Figure 2, and as already discussed, there is large variation in the prevalence of overwork across occupations in each decade and over time. The majority of occupations have also experienced a rise in the prevalence of overwork from 
1980 to 2010.

To formally examine the relationship between changes in the prevalence of overwork and the female occupational distribution, we estimate the following baseline regression:

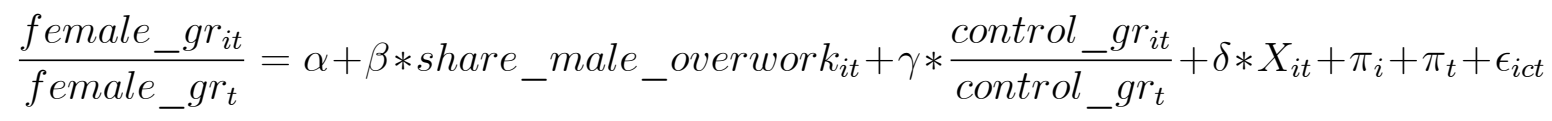

where $i$ refers to an occupation and $t$ refers to each decade. Female_gr refers to the female demographic group of interest; for example, college-educated females age 25 to 40 that are married with children. Control_gr refers to another demographic group in the same age range as the outcome variable, but comprise individuals who face arguably lower costs of providing long work hours (e.g. single women, married women without children, or males). In all specifications, we include occupation and year fixed effects to capture time-invariant characteristics of the occupation that are correlated with the prevalence of overwork, and year-specific shocks that are common to all occupations due, for instance, to changes in aggregate economic conditions. In some specifications, we also include controls $\left(X_{i t}\right)$ that vary by occupation and year that might be correlated with the prevalence of overwork and that are likely to have an independent effect on occupational distributions such as average log wages and the standard deviation of log wages of males and females in an occupation. All the regressions are weighted by the total number of individuals in the occupation (as defined by the outcome variable) in 1980 and standard errors are clustered at the occupation level.

Table 1 presents the estimates of equation (1) for college-educated females. Columns (1) to (5) focus on the occupational distribution of married women age 25 to 40 with at least one child, presumably the group with the highest cost of providing long hours. Col- 
umn (1) reports the coefficient estimate of $\beta$, controlling only for occupation and year fixed effects. The estimated coefficient is negative and marginally significant at the 10 percent level. Column (2) includes additional controls for the average and standard deviation of log female and males wages. The magnitude of the estimated coefficient remains similar, and is now statistically significant at the 5 percent level. Overall, these results indicate that as the share of males working overtime in an occupation increases, the employment share of college-educated females with young children in that occupation declines.

To address concerns that our estimates may capture occupation-specific demand shocks that are correlated with the prevalence of overwork and the occupational distribution of married females with children, in Columns (3), (4) and (5), we include controls for the occupational distribution of other subgroups (males, single females and married females without children) of the same age range who are likely to be less sensitive to increases in the demand for overtime work. The coefficient estimates are essentially unchanged. To the extent that the control subgroups face similar demand shocks as our demographic group of interest (married females with children), these results provide some assurance that our estimates are not just picking up unobserved demand shocks, but reflect the lower willingness of married women with young children to remain in occupations with a higher prevalence of overwork due to their higher costs of providing long hours of work. Additionally, the fact that the results continue to hold after controlling for the occupational distribution of married females who are childless suggests that the prevalence of overwork in an occupation is not merely proxying for other skills valued by the occupation, for which there might be gender differences, such as competitiveness and risk-taking. The magnitude of our preferred estimate in Column (3) indicates that a one standard deviation increase in the share of males working 50+ hours in an occupation (about 10 percentage points) leads to a 1.5 percentage point (0.17 standard deviation) decline in the share of young married females with children 
working in that occupation.

To further illustrate that the effects of the prevalence of overwork on the occupational choice of married women with children are likely to be driven by the cost of providing long hours of work, rather than other unobservable characteristics of this group of women or timevarying occupational characteristics, we estimate a series of "placebo" regressions where we examine the effects of male overwork on the occupational distribution of groups of women and men with limited childcare responsibilities. The groups we consider include married women age 25-40 with no children (Column (6)), single women age 25 to 40 (Column (7)), married women age 41-54 with children (Column (8)), and males age 25 to 40 (Column (9)). In each of these specifications, except for the last column, we control for the occupational distribution of males of the same age range as well as the average and standard deviation of log wages of female and males. The coefficients on the prevalence of overwork are much smaller in magnitude, and are not statistically significant for all of these subgroups. These results indicate that married women with young children are the most responsive to changes in the demand for overwork. This pattern is consistent with the idea that that the key channel through which the prevalence of overwork affects female occupational choice is by reducing the desirability of the work environment for women with family responsibilities. Moreover, these results also provide us with some assurance that the our preferred estimates are unlikely to be driven by unobservable demand shocks since such shocks should also affect the occupational choice of women with limited childcare responsibilities.

So far, we have ignored the possibility that forward-looking young women may choose family-friendly occupations in anticipation of future work-family conflicts. Given the tenyear time frame used in the analysis, changes in the prevalence of overwork in a given decade could potentially affect the occupational choices of young women between the ages of 25 to 30, regardless of whether they are single or married. In regressions not reported here, we 
explore the relationship between an occupation's prevalence of overwork and the occupational distribution of young women - we find a negative, but small and non-statistically significant coefficient. ${ }^{16}$ This suggests that women largely respond to changes in the prevalence of overwork in an occupation when they are faced with greater constraints on their time i.e. at the point when they have children, rather than choosing occupations in anticipation of future family considerations.

Table 2 reports the results from several robustness tests. First, we address concerns that the use of $50+$ hours per week as the threshold for overwork, following the practice of the current literature (e.g. Cha and Weeden, 2014, Kuhn and Lozano, 2008), is somewhat arbitrary. Panel A of Table 2 reports the coefficient estimates using alternative definitions of overwork to construct the key independent variable of interest, namely, the share of males age 25 to 54 working $41+, 45+, 50+$, and $55+$ hours per week. The coefficients on the prevalence of overwork defined using a threshold of 41, 45, and 50 hours per week, are negative and statistically significant at the 5 percent level. The coefficient on the prevalence of overwork defined using a threshold of 55 hours is also negative and similar in magnitude to that of the baseline coefficient on the prevalence of overwork defined using a threshold of 50 hours, but is only marginally significant at the 10 percent level. Overall, this exercise suggests that the results are largely robust to alternative definitions of the prevalence of long work hours.

Next, we address the concern that the observed relationship between the prevalence of overwork in an occupation and the occupational choice of young married females could, in fact, be due to endogeneity in the prevalence of overwork in an occupation. For example, one might be concerned that an influx of young mothers to an occupation may result in an occupation offering better amenities such as more flexible hours in order to accommodate the

\footnotetext{
${ }^{16}$ The coefficient on the prevalence of overwork in a regression where the dependent variable is the occupation distribution of all women aged 25 to 30, controlling for the occupational distribution of similarly aged males is -0.013 with a standard error of 0.022 . By contrast, the same coefficient when we use the distribution of married females aged 25 to 30 with children is -0.083 with a standard error of 0.046 .
} 
preferences of these workers. ${ }^{17}$ To examine whether the observed changes in the occupational choices of young married females is a cause rather than an effect of changes in an occupation's prevalence of overwork, we present dynamic specifications in which we include a lead of the overwork variable. Using the insights of Sims (1972) and the concept of Granger causality, we look for evidence of causality by noting whether changes in the occupational distribution of women preceded increases in the prevalence of overwork in an occupation. If the prevalence of overwork in an occupation causes women to leave that occupation, but not vice versa, then the lead of the overwork variable (at time $t+1$ ) should not be correlated with the occupational distribution of women at time $t$.

The results from this exercise are reported in Panel B of Table 2. For this specification, since we include ten-year leads of the prevalence of overwork in an occupation, we have to drop observations from 2010. Column (1) reports the coefficient on the prevalence of overwork in an occupation at time $t$ corresponding to the baseline specification controlling for the occupational distribution of males, using this restricted sample. The coefficient estimate (-0.179) is significant at the 10 percent level, and is similar in size to the baseline estimate (0.154) using the full sample as reported in Column (3) of Table 1. The decline in statistical significance is likely due to the smaller number of observations. Column (2) includes the lead of the prevalence of long hours in an occupation. The coefficient on the prevalence of overwork at time $t$ falls slightly to -0.147 , but retains its significance at the 10 percent level. The estimated coefficient on the lead is negative, and significant at the 10 percent level, but is about $40 \%$ smaller in magnitude relative to the contemporaneous effect. When we control for the occupational distribution of single females (Column (3)) and married females with no children (Column (4)), the estimated coefficients on the lead terms are much smaller, and are not statistically significant. The magnitude and significance of the contemporaneous effect

\footnotetext{
${ }^{17}$ This is akin to a violation of the parallel trends assumption in our fixed effects framework.
} 
remain qualitatively unchanged relative to the baseline estimates. Overall, these results suggest that the observed relationship between the prevalence of overwork in an occupation and female occupational choices are unlikely to be driven by reverse causality.

\subsubsection{Suggestive Evidence on Underlying Mechanisms}

Having documented that the prevalence of overwork affects the occupational choices of skilled young mothers, in this section, we provide some suggestive evidence on the underlying mechanisms. The empirical tests that we consider draw on the implications of the theoretical framework developed in Section 2. As discussed previously, an implication of the household model (assuming that workers cannot freely choose their hours in an occupation) is that the observed negative relationship between the prevalence of overwork in an occupation and females' decisions to enter or remain in that occupation is likely to be the result of two different scenarios (or a combination of both). In the first situation, we assume that husbands and wives have the same preferences and productivity within the household, but husbands earn more than their wives. The second case arises when women, in fact, face higher wages than their husbands, but they are more productive at home, place a higher value on the household good, or suffer some disutility from working in the market. We will provide some empirical evidence that attempts to tease apart these different explanations.

To examine whether the differential effect of overwork on the occupational choice of males and females is driven by the intra-household allocation of labor due to higher wages of husbands relative to their wives, we restrict our sample to couples, and divide the sample into different groups based on the relative education or relative expected earnings of members of the couple. The measure of expected earnings is constructed based on demographic characteristics. In particular, we assign each individual in a Census year the median hourly wage of the demographic group that he or she belongs to, defined based on gender, age, 
and education. ${ }^{18}$ Our hypothesis is that if relative wages are the main channel driving the observed relationship between the prevalence of overwork and female occupational choice, we should observe a much larger effect for women with lower education or expected earnings relative to their husbands. Table 3 reports the coefficient estimates from the regression of the occupational distribution of married individuals age 25 to 40 with children on the prevalence of overwork in an occupation separately for different groups of women (and men) depending on whether she (he) has less education, similar education, or more education than her (his) spouse (Columns (1) to (3) and (6) to (8)), as well as whether she (he) has lower or higher predicted hourly wages relative to her (his) spouse (Columns (4) to (5) and (9) to (10)). We find that the effects of the prevalence of overwork are remarkably similar for all groups, and is somewhat larger in magnitude (though not statistically significantly so) for women who have higher expected earnings than their husbands. Interestingly, and supporting the relative wage channel, we find that husbands who have lower earnings potential than their wives appear to switch occupations or drop out of the labor force in response to an increase in the prevalence of long work hours in their occupation (see Column (9)).

\section{Cross-sectional Evidence using Variation in Hours of Work across College Majors}

To examine the different channels through which the prevalence of long hours has an effect on skilled women's occupational choices in greater detail, we turn to data on college majors from the 2009 to 2014 American Community Survey (ACS). The advantage of the cross-sectional analysis using the ACS data is two-fold. First, we are able to construct an individual-level outcome - labor force participation - which allows us to show that at least part of the effect of the prevalence of overwork on the occupational distribution of skilled women appears to be operating through the decision of whether or not to participate in the

\footnotetext{
${ }^{18}$ The education classification that we use is: high school dropouts, high school graduates, some college, college graduates, and graduate education.
} 
labor force, and not just through switching occupations. ${ }^{19}$ Second, using the ACS data, we are able to control for individual-level partner or couple-level characteristics, permitting us to address the issue of assortative matching. However, an important limitation of the ACS data is that given the relatively short time period for which data on the college major is available, we are not able to exploit variation over time, and have to rely on cross-sectional variation. For this reason, we present the analysis as suggestive and as a complement to the panel exercise.

Before turning to the empirical analysis using the ACS data, we address potential concerns that the presence of unobservable confounding factors may preclude us from drawing meaningful inferences from cross-sectional comparisons of occupations, by re-estimating the baseline relationship between occupational choice and the prevalence of overwork in an occupation as shown in equation (1) separately by decade, using only variation across occupations. As shown in Appendix Table 5, for each decade, the coefficient on the prevalence of overwork estimated using the cross-section of occupations is negative, statistically significant, and the magnitude is quite similar to that from the panel exercise as reported in Table 1, Column (3). This finding that the panel data estimates and the cross-sectional estimates are similar when we control for the occupational distribution of males, as well as the cross-occupational differences in male and female wages, provides us with some assurance that the cross-sectional correlations are not merely picking up unobservable differences across occupations.

To examine the effects of the prevalence of long work hours in a given college major field on the labor force participation decisions of individuals in that major, we estimate regressions of the form:

$$
L F P_{i f}=\alpha+\beta * \text { share_male_overwork } k_{f}+X_{i}^{\prime} \varphi+\varepsilon_{i f}
$$

\footnotetext{
${ }^{19}$ We were not able to examine this margin of adjustment in the previous analysis using Census data as we do not have information about an individual's previous occupation if she has dropped out of the labor force more than five years ago or if she has switched occupations.
} 
where $i$ refers to an individual and $f$ refers to the college degree field. ${ }^{20}$ The vector $X_{i}$ includes individual level characteristics, such as age fixed effects, education fixed effects (professional, masters or $\mathrm{PhD}$ degree), and race fixed effects. For married women, we also include fixed effects for spouse's education, age, and college degree field. Standard errors are clustered at the degree field level. As in the panel analysis, we estimate model (2) separately by demographic group. The results are reported in Table 4. Column (1) of Panel A shows that there is a negative and statistically significant correlation between the prevalence of long hours in a degree field and labor force participation for married women aged 25-40 with children. The estimated effects are about 50 to 60 percent smaller (in absolute value) for married females with no children and single women without children (Panel A, Columns (2) and (4), respectively). The coefficient for single mothers with children is close to zero and not statistically significant (Panel A, Column (3)), suggesting that this group of women may not be able to afford to drop out of the labor force in response to an increase in the prevalence of overwork. The coefficient estimate for married men with children (Panel A, Column (5)) is marginally significant at the 10 percent level, but the magnitude of the coefficient is about a tenth of the size of that of their female counterparts.

In Panel B of Table 4, we focus on married individuals aged 25 to 40 with children and estimate equation (2) with additional controls for detailed spouse-level characteristics - which helps partially address self-selection issues - and for different subpopulations. In Column (1), we examine women's labor force participation decisions, including fixed effects for husband's age, education, and degree field. Controlling for these spousal characteristics reduces the coefficient on the prevalence of overwork by about 30 percent; nevertheless, the coefficient remains sizable and statistically significant at the 10 percent level. In Column (2), we restrict the sample to couples in different fields to examine whether the observed effects

\footnotetext{
${ }^{20}$ There are 175 degree fields. The classification used in the ACS is relatively narrow; examples include English language and literature, electrical engineering, biology, etc.
} 
are due to assortative matching. The coefficient estimate remains quite similar, suggesting that the results are unlikely to be entirely driven by assortative matching and income effects. The next two columns divide the sample into those where the woman is expected to earn a lower hourly wage based on her degree field, age, and education relative to her husband (Column (3)), and those where women are expected to earn more (Column (4)). The final two columns divide the sample in a similar way, but for males. It is worth pointing out that, based on observable demographics, about 45 percent of women in this sample are expected to earn more than their husbands. This relatively high fraction can be explained by the large share (approximately 30 percent) of college-educated women who marry someone with less than a bachelor's degree. ${ }^{21}$

As predicted by our simple model, the coefficient on the prevalence of overwork is larger for the sample of women expected to earn less than their husbands; nonetheless, the coefficient is large and statistically significant at the 10 percent level for women who are predicted to earn more than their husbands. Interestingly, and consistent with the results obtained in the panel exercise, the prevalence of overwork appears to affect the labor force participation decisions of men who have lower predicted wages than their spouses. The estimated effect for the sample of men with higher potential earnings than their spouse is very small, and not statistically significant. Overall, these results suggest that the labor force participation decisions of women are more sensitive to the demand for long hours of work, both because they are more likely to be secondary earners in the household, as well as potentially due to women placing a higher value on the household good, men/women placing different values on women's time spent in the market, or greater productivity of women in household production.

\footnotetext{
${ }^{21}$ Conditional on the husband having at least a college degree, about 21 percent of women are predicted to earn more than their husbands.
} 


\section{Evidence from a Panel of European Countries}

In this section, we examine the relationship between the prevalence of working long hours and skilled women's occupational choice using a panel of European countries. We view this empirical exercise as a strong robustness check on our findings since it utilizes data from a difference source, and uses a different source of variation. In particular, by including the country dimension to the occupation-year panel, we are able to control for occupation*year fixed effects, which can account for unobserved shocks to occupations that vary over time (but are common across countries). Furthermore, if the results using the European panel are similar to that of the US analysis, this would provide strong evidence that the findings for the US are generalizable to a broader set of developed countries.

\subsection{Data and Descriptive Statistics}

The data for the cross-country exercise is drawn from the European Union Labor Force Survey (EU-LFS) which covers all 28 member states and Iceland, Norway, and Switzerland. ${ }^{22}$ For comparability, we restrict the sample to the largest and most developed countries ${ }^{23}$ for which data on household demographics for more than one year is available. The countries in our sample include Austria, Belgium, France, Germany, Greece, Ireland, Italy, the Netherlands, Spain, Portugal, and the United Kingdom. ${ }^{24}$ The EU-LFS spans a relatively long time period, beginning in 1983, and includes basic worker characteristics such as education, age, gender, occupation, and hours worked. We restrict our analysis to the 1998 to 2010

\footnotetext{
${ }^{22}$ The EU-LFS is a harmonized data set. The labor force surveys are conducted by the national statistical institutes across Europe and are centrally processed by Eurostat. The national statistical institutes are responsible for selecting the sample, preparing the questionnaires, and conducting the direct interviews among households.

${ }^{23}$ We exclude Luxembourg, Iceland, Malta, Cyprus, and all the Eastern European countries.

${ }^{24}$ Denmark, Finland, Sweden, and Switzerland do not have data on household demographics, and therefore we do not have information on the presence of children in the household. As such, they are excluded from the analysis.
} 
data as household variables are only available beginning in 1998. We further restrict the sample to individuals aged 23 to 57 - the EU-LFS codes age in five-year intervals, which prevents us from using the identical age range as in the US exercise. Given the significantly smaller sample sizes of the labor force surveys compared to the US Census, to ensure sufficient observations to construct the country-occupation-year panel, we use a a much broader occupational classification. Specifically, we group the occupations in the EU-LFS into 20 broader occupation groups. ${ }^{25}$

As shown in Appendix Figure 1, there is wide variation in the prevalence of overwork (defined as the share of full-time college-educated males working $50+$ hours per week) across countries. Nonetheless, none of the European countries have rates of overwork that exceed that of the US. Among the European countries in our sample, the prevalence of long work hours is highest in the UK, France, and Austria, ${ }^{26}$ exceeding 25 percent in 2010 . The prevalence of overwork is also relatively high in Belgium, Germany, and Italy. The rate of overwork among men is particularly low (less than 15 percent in 2010) in the Netherlands. There is also significant variation in the prevalence of overwork across occupation groups in the cross-country sample; as in the US, managers, health professionals, and legal professionals have the highest share of males reporting working 50 or more hours per week (close to 40 percent), while public administration professionals and clerks report the lowest incidence of long work hours (see Table 5).

Not surprisingly, as shown in Table 5, the occupational distribution of women and men are quite different - relative to females, a greater share of males are employed as managers,

\footnotetext{
${ }^{25}$ Appendix Table 6 presents the classification scheme used to construct the occupation groups.

${ }^{26}$ The large increase in the prevalence of overwork in Austria and its high level in 2010 is surprising and likely does not represent a real phenomenon. We checked our code and the questionnaires, but were not able to find a mistake or a change in how the question about hours worked was asked. We hope that including country*year fixed effects in the specification will deal with any potential problem and that measured relative changes across occupations are accurate. In any case, the results are robust to excluding Austria from the sample.
} 
natural/life science professionals, and engineers. Young women with children tend to concentrate in occupations such as educators and associate professionals (excluding business). As expected, married females are also more likely to be out of the labor force. Importantly, for our purpose, there appears to be a substantial degree of variation in the prevalence of overwork and the occupational distribution of women within occupations, over time, and across countries.

\subsection{Cross-country Evidence on the Prevalence of Overwork and Occupational Choice}

To estimate the relationship between changes in the prevalence of overwork and the female occupational distribution in our cross-country panel, we estimate the following regression:

$\frac{\text { female_}_{\text {em }} r_{i c t}}{\text { female_gr }}=\alpha+\beta *$ share_male_overwor $k_{i c t}+\gamma * \frac{\text { control_g }}{\text { control_grt } g r_{c t}}+\pi_{i}+\pi_{c}+\pi_{t}+\pi_{i t}+\pi_{c t}+\pi_{i c}+\epsilon_{i c t}$

where $i$ refers to an occupation, $c$ refers to country, and $t$ refers to the year. As in the previous analysis using US data, the outcome variable $\frac{f e m a l e \_g r_{i c t}}{f e m a l e_{-} g r_{c t}}$ is the occupational distribution of females of a given demographic group in country $c$ in a given year, measured as the share of females in that demographic group working in occupation $i$ in country $c$ in year $t$. The key dependent variable, share_male_overwor $k_{i c t}$, is the share of full-time college-educated males who report working 50 or more hours per week in each occupation,

country, and year. $\frac{\text { control_grict }}{\text { control_grct }}$ is the occupational distribution of another demographic group in the same age range as the outcome variable, but comprise individuals who face lower costs of providing long work hours (e.g. males or females without children).

This specification differs from that used for the US analysis in two ways. First, we include 
country fixed effects, country*year fixed effects, and occupation*year fixed effects. Second, we do not include controls for male and female wages as the EU-LFS does not have data on income. We include observations every five years as a compromise between replicating the US exercise (which considers 10-year changes) and ensuring that we have a sufficient number of observations in our panel. To account for the fact that occupations can vary considerably in terms of size, we weight the observations using regression weights that are constructed based on the total number of individuals in the occupation, normalized to an average of one for each country and year. For all the specifications, standard errors are clustered at the country level.

Table 6 presents the estimates of equation (3). Qualitatively, the results from the crosscountry exercise are very similar to the findings from the US exercise: an increase in the prevalence of long hours in an occupation reduces the share of young mothers in that occupation, ${ }^{27}$ but not the share of other groups (females with no children, older women, and men). The magnitude of the effects using the cross-country data tend to be smaller - our preferred estimate in Column (2) implies that a one standard deviation increase in the share of males working long hours reduces the share of young mothers working in that occupation by 0.07 to 0.1 standard deviations. The larger effects observed in the US analysis could be due to the greater degree of occupational mobility across the detailed occupational categories available in the US data. Moreover, as the US data is based on ten-year changes, the estimates from the US analysis are likely to capture longer-run effects, which are likely to be larger than the medium term (five-year) effects estimated using the cross-country data.

Finally, Table 7 presents some robustness tests that show that the results are generally robust to alternative definitions of the threshold of overwork and are unlikely to be driven by reverse causality. As shown in Panel A, the results typically have the same sign and remain

\footnotetext{
${ }^{27}$ We do not define demographic groups based on marital status given the high prevalence of cohabitation in some European countries.
} 
statistically significant, although the magnitude is somewhat smaller when we use alternative thresholds for overwork (e.g. working $41+$ or $45+$ hours per week). The only exception is that the coefficient estimate is no longer statistically significant when we use a $55+$ hours as the threshold for overwork - nevertheless, this result may not be that surprising, since unlike the US, working such long hours remains quite uncommon in most European countries. In Panel B, we augment the baseline model with a lead of the prevalence of overwork variable. The estimated coefficient on the lead is small and not statistically significant, suggesting that the prevalence of long hours in an occupation is unlikely to be endogenous to the share of young mothers choosing an occupation.

\section{Conclusion}

The recent literature and public debate suggest that institutional factors such as inflexible job characteristics - long hours, inflexible schedules and working conditions - continue to hinder women's progress in the labor market (Goldin, 2014, Fouad, 2012, Slaughter, 2015). In this paper, we empirically examine how one particular aspect of workplace flexibility - the share of males working 50 or more hours per week - affects women's decisions to participate in the labor market and their occupational choice. Our results suggest that the prevalence of overwork has a large effect on the occupational choices of young, educated married mothers.

Our theoretical model and some of our empirical results point to the differential impact of the demand for long hours across genders as being driven by a women's role as secondary earners in the household, as well as differences in preferences, gender roles, or productivity in the household sector. This suggests that as women close the gap in education and human capital investments, the fact that they continue to bear a disproportionate burden of household responsibilities imply that occupational differences such as inflexible work hours 
and workplace conditions are particularly costly for women, and are likely to emerge as increasingly important determinants of gender differences in occupational choice and earnings (Blau and Kahn, 2016). As more women seek to effectively combine career and family goals, polices to enhance workplace flexibility are likely to go a long way in reducing occupational segregation and reducing gender disparities in the labor market.

One limitation of our study is that we are unable to shed light on why some occupations have a higher prevalence of overwork than others and why the demand for overwork has increased differentially across occupations and countries. We suspect that proximate factors include changes in compensation schemes, technological change, and globalization. These factors may have increased the demand for employees to be available whenever clients or supervisors need them, and led to changes in organizational practices and workplace cultures (Cha and Weeden, 2014). On the other hand, there are several occupations that have successfully reduced the costs of substituting across employees, thereby increasing hours flexibility in those jobs. The causes of these changes are varied - for example, in the case of pharmacists, Goldin (2014) points to the increased standardization of procedures and drugs (through the effective use of IT systems) in allowing pharmacists to become better substitutes for each other. Moreover, exogenous changes in the market structure in the form of increased corporate ownership and hospital employment also led to more flexible employment opportunities. Other examples of occupations that have enhanced workplace flexibility by creating teams of employees can substitute for one another include obstetricians, anesthesiologists, and some occupations in the banking and real estate sectors (Blair-Loy 2009, Goldin, 2015). Our study highlights the need for a better understanding of the determinants of the demand for overwork and workplace inflexibility to facilitate the design of policies to address their negative effects on female labor market outcomes. 


\section{References}

[1] Aguiar, Mark and Erik Hurst. 2007. "Measuring Trends in Leisure: The Allocation of Time Over Five Decades." Quarterly Journal of Economics. Vol. 122(3): 969-1006

[2] Akerlof, George and Rachel Kranton. 2000. "Economics and Identity." Quarterly Journal of Economics. Vol 115(3): 715-753.

[3] Bianchi, Suzanne M., Melissa A. Milkie, Liana C. Sayer, and John P. Robinson. 2000. "Is anyone doing the housework? Trends in the gender division of house- hold labor." Social Forces. Vol. 79:191-228.

[4] Blair-Loy, Mary. 2009. "Work without End?: Scheduling Flexibility and Work-to-Family Conflict among Stockbrokers." Work and Occupations. Vol. 36(4): 279-317.

[5] Blau, Francine D. 2012. "The Sources of the Gender Pay Gap." Pp. 189?210 in The New Gilded Age: The Critical Inequality Debates of Our Time, edited by D. B. Grusky and T. Kricheli-Katz. Stanford: Stanford University Press.

[6] Blau, Francine D. and Lawrence M. Kahn. 2006. "The U.S. Gender Pay Gap in the 1990s: Slowing Convergence." Industrial and Labor Relations Review. Vol. 60 (1): 4566.

[7] Blau, Francine D. and Lawrence M. Kahn. 2013. "Female Labor Supply: Why Is the United States Falling Behind?." American Economic Review, 103(3):251-56.

[8] Blau, Francine D. and Lawrence M. Kahn. 2016. "The Gender Wage Gap: Extent, Trends, and Explanations." NBER Working Paper 21913.

[9] Cha, Youngjoo. 2013. "Overwork and the Persistence of Gender Segregation in Occupations." Gender \& Society. Vol. 27(2): 158-184. 
[10] Cha, Youngjoo and Kim A. Weeden. 2014. "Overwork and the Slow Convergence in the Gender Gap in Wages". American Sociological Review. Vol. 79(3): 457-484

[11] Cortes, Patricia and Jessica Pan. 2016. "When Time Binds: Returns to Working Long Hours and the Gender Wage Gap among the Highly Skilled". IZA DP No. 9846.

[12] Dorn, David. 2009. "Essays on Inequality, Spatial Interaction, and the Demand for Skills." Dissertation University of St. Gallen no. 3613.

[13] Flabbi, Luca and Andrea Moro. 2012. "The Effect of Job Flexibility on Female Labor Market Outcomes: Estimates from a Search and Bargaining Model." Journal of Econometrics. Vol. 168(1): 81-95.

[14] Fouad, Nadya A., Romila Singh, Mary E. Fitzpatrick, and Jane P. Liu. 2012. "Stemming the Tide: Why Women Leave Engineering" NSF Report, 101d98c.

[15] Goldin, Claudia. 2015. "Career and Family: Collision or Confluence." Presentation at the 8th Annual Kenneth Arrow Lecture, Columbia University, December 10, 2015.

[16] Goldin, Claudia. 2014. "A Grand Gender Convergence: Its Last Chapter." American Economic Review. Vol.104(4): 1091-1119.

[17] Goldin, Claudia and Lawerence F. Katz. 2011. "The Cost of Workplace Flexibility for High- Powered Professionals." The Annals of the American Academy of Political and Social Science. Vol. 638: 45-67.

[18] Guryan, Jonathan, Erik Hurst, and Melissa Kearney. 2008. "Parental Education and Parental Time with Children." Journal of Economic Perspectives. Vol. 22(3): 23-46. 
[19] Herr, Jane L. and Catherine D. Wolfram. 2012. "Work environment and opt-out rates at motherhood across high-education career paths." Industrial and Labor Relations Review. Vol. 65(4): 928?950.

[20] Kuhn, Peter J. and Fernando A. Lozano. 2008. "The Expanding Workweek? Understanding Trends in Long Work Hours among U.S.Men, 1979-2006." Journal of Labor Economics. Vol. 26: 311-43.

[21] Lim, Katherine. 2015. "Self-Employment, Workplace Flexibility, and Maternal Labor Supply, A Life-Cycle Model." Working Paper.

[22] Pertold-Gebicka, Barbara, Filip Pertold, and Nabanita Datta Gupta. 2016. "Employment Adjustments around Childbirth." IZA Discussion Paper No. 9685.

[23] Sims, Christopher. 1972. "Money, Income, and Causality." American Economic Review. Vol. 62: 540-552.

[24] Slaughter, Anne Marie. 2015. "Unfinished business: Women Men Work Family." New York: Random House.

[25] Snyder, Kieran. 2014. "Why Women Leave Tech: It's the Culture, not because "Math is Hard"." Fortune 2 Oct. 2014.

[26] Stone, Pamela. 2007. Opting out?: Why women really quit careers and head home. Berkeley: University of California Press.

[27] Wasserman, Melanie. 2015. "Hours Contraints, Occupational Choice and Fertility: Evidence from Medical Residents." MIT Working Paper.

[28] Wiswall, Matthew and Basit Zafar. 2016. Preference for the Workplace, Investment in Human Capital, and Gender. Working Paper. 
Figure 1. Share of males working 50+ hours per week by education and year

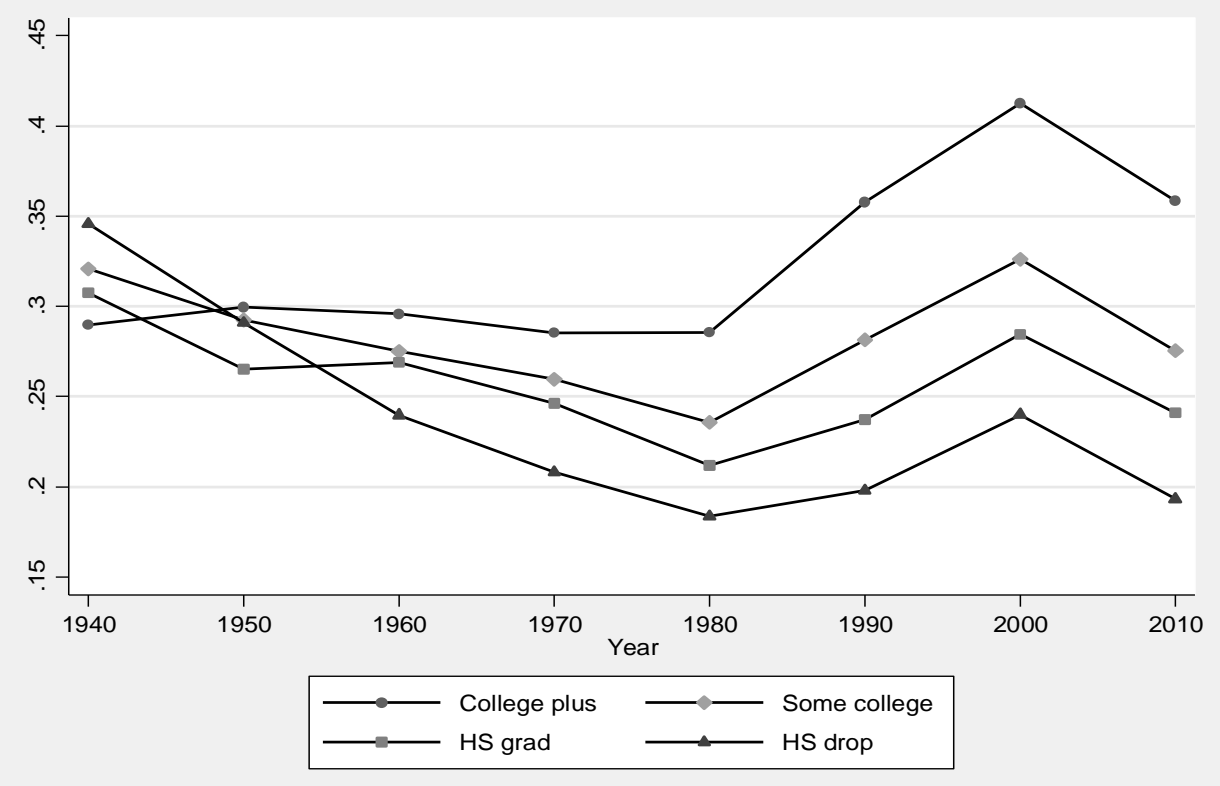

Notes: The data is from the 1940 to 2000 US Census and the 2010-2012 ACS. The sample is restricted to nativeborn males age 25 to 54 who report working full-time (35 hours or more) in a given week.

Figure 2. Cross-occupation relationship between the prevalence of overwork and the gender gap in employment share
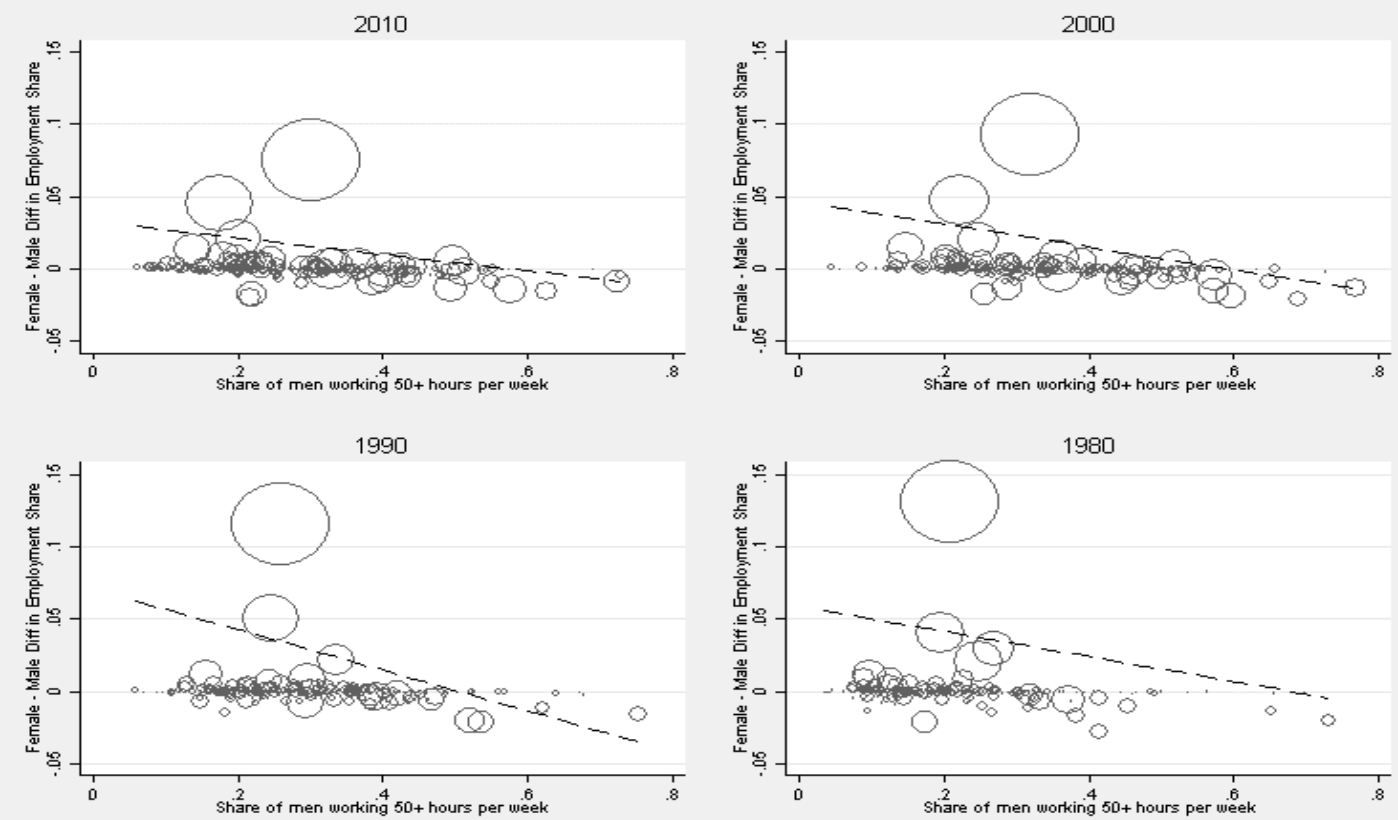

Notes: The data is from the 1980 to 2000 US Census and the 2010-2012 ACS. The sample is restricted to nativeborn individuals age 25 to 54 with at least a college degree who report working full-time (35 hours or more) in a given week. The figures include 215 consistently defined occupations and is weighted by the number of females in each occupation. 


\begin{tabular}{|c|c|c|c|c|c|c|c|c|}
\hline \multicolumn{7}{|c|}{ Married Females age 25-40 } & \multirow{3}{*}{$\begin{array}{c}\text { Married } \\
\text { Females age } \\
41-54 \\
\text { With Children } \\
\text { (8) }\end{array}$} & \multirow{3}{*}{$\begin{array}{c}\text { Males age } \\
25-40 \\
\text { Both } \\
(9)\end{array}$} \\
\hline \multicolumn{5}{|c|}{ With Children } & No Children & Single & & \\
\hline$(1)$ & $(2)$ & (3) & (4) & (5) & (6) & $(7)$ & & \\
\hline$-0.186 *$ & $-0.158^{* *}$ & $-0.154 * *$ & $-0.121 * *$ & $-0.149 * *$ & 0.004 & -0.016 & -0.052 & -0.001 \\
\hline [0.104] & {$[0.067]$} & {$[0.070]$} & [0.053] & [0.065] & [0.019] & [0.028] & [0.065] & [0.009] \\
\hline
\end{tabular}

hours

in occupation $i$ :

Share of individuals of the same age working in occupation $i$ :

Males

Single females

Married females without children

Average and standard deviation of log male and female wages

Occupation FE

Year FE

Observations

R-squared

0.960

\section{$0.839 * * *$ \\ [0.206]}

$$
0.732 * * *
$$

\section{[0.084]}

$\begin{array}{ccc}2.224 * * * & 1.840^{* * *} & 3.825^{* * *} \\ {[0.604]} & {[0.528]} & {[0.554]}\end{array}$

$\begin{array}{ccc}2.224 * * * & 1.840^{* * *} & 3.825^{* * *} \\ {[0.604]} & {[0.528]} & {[0.554]}\end{array}$

$0.577 * * *$

[0.088]

Notes: The data is from the 1980 to 2000 US Census and the 2012 3-year aggregate ACS. The unit of observation is an occupation by year. The regressions include 215 occupations and four decades. The average and standard deviation of log female and male wages are computed for full-time workers age 25 to 54 . The regressions are weighted by the number of workers (as defined by the outcome) in the occupation in 1980. Standard errors clustered at the occupation level are reported in brackets. $* * *$ significant at the $1 \%$ level, $* * 5 \%, * 10 \%$. 
Share of males age 25 to 54 working $\mathrm{X}+$ hours

Controlling for occupation distribution of:

Share of males age 25 to 54 working $50+$ hours

Share of males age 25 to 54 working $50+$ hours, $t+1$

Controlling for occupation distribution of:

Average and standard deviation of log male and female wages

Occupation FE

Year FE
Dep. Var: Share of College Educated Married Females age 25-40 with Children working in occupation $i$

A. Definitions of Overwork

(2)

(3)

(1)

$$
\mathrm{X}=45
$$

$\mathrm{X}=50$

$\mathrm{X}=55$

$-0.102^{* *}$

$-0.121^{* *}$

$-0.154^{* *}$

$-0.131 *$

[0.049]

[0.054

[0.070]

[0.071]

Males

Males

Males

Males

$-0.179 *$

[0.091]

B. Leads

(2)

(3)

$-0.147^{*} \quad-0.150$ *

$-0.147 *$

[0.084] [0.082]

[0.080]

$\begin{array}{lll}-0.094 * & -0.044 & -0.043 \\ {[0.052]} & {[0.029]} & {[0.029]}\end{array}$

Males

Single

Married no

Males females

children

Notes: The data is from the 1980 to 2000 US Census and the 2012 3-year aggregate ACS. The unit of observation is an occupation by year. The number of observations is 860 for Panel A and just 645 for Panel B as we have to drop the year 2010. The regressions are weighted by the number of workers (as defined by the outcome) in the occupation in 1980 . Standard errors clustered at the occupation level are reported in brackets. ***significant at the $1 \%$ level, **5\%, ${ }^{*} 10 \%$. 
Table 3. Relationship between the prevalence of working long hours and occupational choices: Identifying mechanisms Individuals aged 25-40 Married and with Children

Women

\begin{tabular}{|c|c|c|c|c|c|c|c|c|c|}
\hline \multicolumn{5}{|c|}{ Women } & \multicolumn{5}{|c|}{ Men } \\
\hline Educatic & $\mathrm{n}$ relative & o Spouse & Predicted $\mathrm{H}$ & Irly Wage & Educati & relative & Spouse & Predicted H & rly Wage \\
\hline $\begin{array}{l}\text { Less } \\
(1)\end{array}$ & $\begin{array}{l}\text { Same } \\
\text { (2) }\end{array}$ & $\begin{array}{l}\text { More } \\
\text { (3) }\end{array}$ & $\begin{array}{l}\text { Lower } \\
\text { (4) }\end{array}$ & $\begin{array}{l}\text { Higher } \\
\text { (5) }\end{array}$ & $\begin{array}{l}\text { Less } \\
\text { (6) }\end{array}$ & $\begin{array}{l}\text { Same } \\
\text { (7) }\end{array}$ & $\begin{array}{l}\text { More } \\
\text { (8) }\end{array}$ & $\begin{array}{l}\text { Lower } \\
\text { (9) }\end{array}$ & $\begin{array}{c}\text { Higher } \\
(10)\end{array}$ \\
\hline $\begin{array}{c}-0.119 * * \\
{[0.058]}\end{array}$ & $\begin{array}{c}-0.145^{* *} \\
{[0.065]}\end{array}$ & $\begin{array}{c}-0.112 * * \\
{[0.046]}\end{array}$ & $\begin{array}{c}-0.116^{* *} \\
{[0.057]}\end{array}$ & $\begin{array}{c}-0.122 * * \\
{[0.049]}\end{array}$ & $\begin{array}{l}-0.012 \\
{[0.010]}\end{array}$ & $\begin{array}{c}-0.020 \\
{[0.017]}\end{array}$ & $\begin{array}{l}-0.006 \\
{[0.006]}\end{array}$ & $\begin{array}{c}-0.047 * * \\
{[0.018]}\end{array}$ & $\begin{array}{c}-0.009 \\
{[0.008]}\end{array}$ \\
\hline
\end{tabular}

Share of males age 25 to 54 working $50+$ hours

$[0.058] \quad[0.065] \quad[0.046$

[0.057]

[0.049]

[0.010]

[0.017]

.018

[0.008]

Share of individuals of the same age, same sex, and single

working in the same occupation

X $\quad X$

$\mathrm{X}$

$\mathrm{X}$

$\mathrm{X}$

$\mathrm{X}$

$\mathrm{X}$

$\mathrm{X}$

$\mathrm{X}$

Average and standard deviation

of log male and female wages

Occupation FE

Year FE

$\begin{array}{ccc}X & X & X \\ X & X & X \\ X & X & X \\ 860 & 860 & 860\end{array}$

$\mathrm{X}$
$\mathrm{X}$
$\mathrm{X}$
860

$\begin{array}{cr}X & X \\ X & X \\ X & X \\ 860 & 860\end{array}$

$\mathrm{X}$
$\mathrm{X}$
$\mathrm{X}$
860

$\mathrm{X}$
$\mathrm{X}$
$\mathrm{X}$
860

$X$
$X$
$X$
860

$\begin{array}{ccc}X & X & X \\ X & X & X \\ X & X & X \\ 860 & 860 & 860\end{array}$

Notes: The data is from the 1980 to 2000 US Census and the 2012 3-year aggregate ACS. The unit of observation is an occupation by year. The regressions include 215 occupations and four decades. The average and standard deviation of log female and male wages are computed for full-time workers age 25 to 54 . Predicted hourly wage is based on education, age, and gender. The "Lower" group includes those with the same predicted wage as their spouses. The regressions are weighted by the number of workers (as defined by the outcome) in the occupation in 1980. Standard errors clustered at the occupation level are reported in brackets. ***significant at the $1 \%$ level, $* * 5 \%, * 10 \%$ 
Table 4. Prevalence of overwork in college degree field and labor force participation: Cross-sectional analysis

\begin{tabular}{|c|c|c|c|c|c|c|c|c|c|c|c|}
\hline \multicolumn{12}{|c|}{ Dep. Var: Labor Force Participation of individual $i$ with degree field $f$} \\
\hline & \multicolumn{5}{|c|}{ Panel A. Individuals age $25-40$} & \multicolumn{6}{|c|}{ Panel B. Married Individuals 25-40 with children } \\
\hline & \multicolumn{2}{|c|}{ Female Married } & \multicolumn{2}{|c|}{ Female Single } & \multirow{2}{*}{$\begin{array}{c}\text { Men Married } \\
\text { Children } \\
\text { (5) }\end{array}$} & \multirow{2}{*}{$\begin{array}{c}\text { All couples } \\
\text { Women } \\
(1)\end{array}$} & \multirow{2}{*}{$\begin{array}{c}\text { Different } \\
\text { fields }\end{array}$} & \multirow{2}{*}{$\begin{array}{c}\text { Predicted to } \\
\text { earn same or } \\
\text { less than } \\
\text { spouse } \\
\begin{array}{c}\text { Women } \\
(3)\end{array}\end{array}$} & \multirow{2}{*}{$\begin{array}{c}\text { Predicted to } \\
\text { earn more than } \\
\text { spouse } \\
\begin{array}{c}\text { Women } \\
(4)\end{array}\end{array}$} & \multirow{2}{*}{$\begin{array}{c}\text { Predicted to } \\
\text { earn same or } \\
\text { less than } \\
\text { spouse }\end{array}$} & \multirow{2}{*}{$\begin{array}{c}\begin{array}{c}\text { Predicted to } \\
\text { earn more } \\
\text { than spouse }\end{array} \\
\begin{array}{c}\text { Men } \\
(6)\end{array}\end{array}$} \\
\hline & $\begin{array}{l}\text { With Children } \\
\text { (1) }\end{array}$ & $\begin{array}{c}\text { No Children } \\
\text { (2) }\end{array}$ & $\begin{array}{l}\text { With Children } \\
\text { (3) }\end{array}$ & $\begin{array}{c}\text { No Children } \\
\text { (4) }\end{array}$ & & & & & & & \\
\hline $\begin{array}{l}\text { Share of males age } 25 \text { to } 54 \\
\text { working } 50+\text { hours with degree }\end{array}$ & $-0.373^{* *}$ & -0.181 & -0.060 & $-0.150 * *$ & $-0.036^{*}$ & $-0.276^{*}$ & $-0.264 *$ & $-0.319 *$ & $-0.195 *$ & $-0.089 *$ & -0.020 \\
\hline field $f$ & {$[0.162]$} & [0.175] & [0.042] & [0.065] & [0.019] & [0.147] & {$[0.153]$} & {$[0.186]$} & {$[0.108]$} & [0.053] & {$[0.018]$} \\
\hline Mean of dep. variable & 0.81 & 0.79 & 0.81 & 0.92 & 0.98 & 0.81 & 0.81 & 0.76 & 0.88 & 0.96 & 0.98 \\
\hline \multicolumn{12}{|l|}{ Controls } \\
\hline Age FE & $\mathrm{X}$ & $\mathrm{X}$ & $\mathrm{X}$ & $\mathrm{x}$ & $\mathrm{X}$ & $\mathrm{x}$ & $\mathrm{X}$ & $\mathrm{X}$ & $\mathrm{X}$ & $\mathrm{X}$ & $\mathrm{X}$ \\
\hline Race dummies & $\mathrm{X}$ & $\mathrm{X}$ & $\mathrm{X}$ & $\mathrm{X}$ & $\mathrm{X}$ & $\mathrm{X}$ & $\mathrm{X}$ & $\mathrm{X}$ & $\mathrm{X}$ & $\mathrm{X}$ & $\mathrm{X}$ \\
\hline Graduate degree FE & $\mathrm{X}$ & $\mathrm{X}$ & $\mathrm{X}$ & $\mathrm{X}$ & $\mathrm{X}$ & $\mathrm{X}$ & $\mathrm{X}$ & $\mathrm{X}$ & $\mathrm{X}$ & $\mathrm{X}$ & $\mathrm{X}$ \\
\hline Age husband FE & & & & & & $\mathrm{X}$ & $\mathrm{X}$ & $\mathrm{X}$ & $\mathrm{X}$ & $\mathrm{X}$ & $\mathrm{X}$ \\
\hline Graduate degree husband FE & & & & & & $\mathrm{X}$ & $\mathrm{X}$ & $\mathrm{X}$ & $\mathrm{X}$ & $\mathrm{X}$ & $\mathrm{X}$ \\
\hline Husband's field FE & & & & & & $\mathrm{X}$ & $\mathrm{X}$ & $\mathrm{X}$ & $\mathrm{X}$ & $\mathrm{X}$ & $\mathrm{X}$ \\
\hline No. Observations & 92,661 & 326,291 & 26,311 & 221,780 & 56,127 & 90,959 & 85,862 & 47,626 & 38,227 & 6,889 & 45,111 \\
\hline
\end{tabular}

weights Standard errors clustered at the degree field level are reported in brackets. $* * *$ significant at the $1 \%$ level, $* * 5 \%, 10 \%$. 
Managers

Natural and Life Sciences, Math and Computing Prof.

Architects and Engineers

Health Professionals

Educators $\mathrm{HR}$, etc)

Legal Professionals

Social Scientists

Writers and Artists

Public Administration Prof.

Associate prof. excl. Business

Business and Finance Ass. Prof.

Administrative Associate Prof.

Religious/social workers

Office clerks

clerks

Service Workers (restaurants, hhlds, etc)

Market salespersons

Precision production, operators, craft

Laborers/elementary occupations

Not in LF or in Military
Business Professionals (Accountants,

Cashiers, tellers, client information and repair occs

\begin{tabular}{|c|c|c|c|c|c|c|c|c|c|c|c|}
\hline \multicolumn{6}{|c|}{1998} & \multicolumn{6}{|c|}{2010} \\
\hline \multicolumn{2}{|c|}{$\begin{array}{c}\text { Share Overwork } \\
\text { FT Males }\end{array}$} & \multicolumn{2}{|c|}{$\begin{array}{c}\text { Share of Mothers } \\
23-42 \text { working in } \\
\text { occ }\end{array}$} & \multicolumn{2}{|c|}{$\begin{array}{c}\text { Share of Males } \\
23-57 \text { working } \\
\text { in occ } \\
\end{array}$} & \multicolumn{2}{|c|}{$\begin{array}{c}\text { Share } \\
\text { Overwork } \\
\text { FT Males } \\
\end{array}$} & \multicolumn{2}{|c|}{$\begin{array}{c}\text { Share of Mothers } \\
23-42 \text { working in } \\
\text { occ }\end{array}$} & \multicolumn{2}{|c|}{$\begin{array}{c}\text { Share of Males } \\
23-57 \text { working in } \\
\text { occ }\end{array}$} \\
\hline Mean & S.D. & Mean & S.D. & Mean & S.D. & Mean & S.D. & Mean & S.D. & Mean & S.D. \\
\hline 0.35 & 0.10 & 0.05 & 0.02 & 0.15 & 0.05 & 0.38 & 0.11 & 0.07 & 0.04 & 0.15 & 0.05 \\
\hline 0.13 & 0.06 & 0.02 & 0.01 & 0.05 & 0.01 & 0.13 & 0.06 & 0.02 & 0.00 & 0.06 & 0.02 \\
\hline 0.22 & 0.07 & 0.02 & 0.01 & 0.09 & 0.03 & 0.22 & 0.08 & 0.02 & 0.01 & 0.09 & 0.03 \\
\hline 0.31 & 0.24 & 0.08 & 0.03 & 0.08 & 0.03 & 0.35 & 0.19 & 0.06 & 0.03 & 0.05 & 0.02 \\
\hline 0.11 & 0.07 & 0.24 & 0.10 & 0.15 & 0.04 & 0.15 & 0.10 & 0.15 & 0.04 & 0.10 & 0.03 \\
\hline 0.30 & 0.25 & 0.02 & 0.01 & 0.03 & 0.02 & 0.29 & 0.18 & 0.03 & 0.02 & 0.04 & 0.02 \\
\hline 0.38 & 0.18 & 0.03 & 0.01 & 0.04 & 0.01 & 0.42 & 0.13 & 0.02 & 0.01 & 0.02 & 0.01 \\
\hline 0.14 & 0.08 & 0.02 & 0.01 & 0.02 & 0.01 & 0.15 & 0.10 & 0.04 & 0.02 & 0.02 & 0.01 \\
\hline 0.30 & 0.15 & 0.01 & 0.01 & 0.02 & 0.01 & 0.26 & 0.09 & 0.02 & 0.01 & 0.02 & 0.01 \\
\hline 0.05 & 0.07 & 0.01 & 0.01 & 0.01 & 0.01 & 0.08 & 0.11 & 0.01 & 0.01 & 0.02 & 0.01 \\
\hline 0.16 & 0.06 & 0.11 & 0.09 & 0.07 & 0.04 & 0.12 & 0.05 & 0.10 & 0.04 & 0.08 & 0.02 \\
\hline 0.29 & 0.13 & 0.01 & 0.01 & 0.03 & 0.02 & 0.24 & 0.10 & 0.03 & 0.01 & 0.04 & 0.01 \\
\hline 0.09 & 0.09 & 0.03 & 0.02 & 0.02 & 0.01 & 0.11 & 0.07 & 0.04 & 0.02 & 0.02 & 0.01 \\
\hline 0.39 & 0.24 & 0.01 & 0.01 & 0.01 & 0.01 & 0.26 & 0.12 & 0.01 & 0.01 & 0.01 & 0.00 \\
\hline 0.05 & 0.03 & 0.08 & 0.05 & 0.04 & 0.03 & 0.07 & 0.05 & 0.09 & 0.03 & 0.04 & 0.02 \\
\hline 0.07 & 0.07 & 0.01 & 0.01 & 0.01 & 0.01 & 0.05 & 0.05 & 0.02 & 0.01 & 0.01 & 0.00 \\
\hline 0.13 & 0.10 & 0.02 & 0.01 & 0.01 & 0.01 & 0.14 & 0.08 & 0.04 & 0.02 & 0.02 & 0.02 \\
\hline 0.16 & 0.09 & 0.01 & 0.01 & 0.01 & 0.00 & 0.16 & 0.10 & 0.02 & 0.01 & 0.01 & 0.01 \\
\hline 0.24 & 0.13 & 0.01 & 0.00 & 0.05 & 0.05 & 0.23 & 0.08 & 0.01 & 0.00 & 0.08 & 0.05 \\
\hline 0.18 & 0.21 & 0.01 & 0.01 & 0.01 & 0.01 & 0.09 & 0.08 & 0.01 & 0.01 & 0.01 & 0.01 \\
\hline & & 0.20 & & 0.10 & & & & 0.17 & & 0.11 & \\
\hline
\end{tabular}

Notes: The data is from the 1998 and 2010 EU-LFS . The unit of observation is a country-occupation-year. The table reports the mean and standard deviation across countries of the various variables. The sample is restricted to individuals aged 23-57 with a college degree. 
Table 6. Relationship between the prevalence of working long hours and occupational choices of college educated women: Country panel

Dep. Var: Share of College Educated working in occupation $i$

\begin{tabular}{|c|c|c|c|c|c|c|c|c|c|}
\hline \multicolumn{5}{|c|}{ Females age $23-42$} & \multicolumn{4}{|c|}{ Females age $43-57$} & $\begin{array}{c}\text { Males age } \\
23-42\end{array}$ \\
\hline \multicolumn{3}{|c|}{ With Children } & \multicolumn{2}{|c|}{ No Children } & \multicolumn{2}{|c|}{ With Children } & \multicolumn{2}{|c|}{ No Children } & Both \\
\hline (1) & (2) & (3) & (4) & (5) & (6) & (7) & (8) & (9) & (10) \\
\hline$-0.088 * *$ & $-0.062 * *$ & $-0.043^{* *}$ & -0.053 & -0.028 & -0.001 & -0.004 & -0.011 & -0.013 & -0.029 \\
\hline [0.038] & [0.022] & [0.016] & [0.033] & {$[0.020]$} & [0.027] & [0.024] & [0.030] & [0.029] & [0.017] \\
\hline
\end{tabular}

Share of individuals of the same age working in occupation $i$ :

Males

$0.911^{* * *}$

[0.212]
$0.853^{* * *}$
$[0.062]$
$0.740 * * *$

[0.127]

$0.855^{* * *}$

[0.205]

Country FE

Year FE

Occupation Group FE

Country x Year FE

Country x Occ FE

Year $\mathrm{x}$ Occ FE

$\begin{array}{ll}X & X \\ X & X \\ X & X \\ X & X \\ X & X \\ X & X\end{array}$

$\begin{array}{lll}\mathrm{X} & \mathrm{X} & \mathrm{X} \\ \mathrm{X} & \mathrm{X} & \mathrm{X} \\ \mathrm{X} & \mathrm{X} & \mathrm{X} \\ \mathrm{X} & \mathrm{X} & \mathrm{X} \\ \mathrm{X} & \mathrm{X} & \mathrm{X} \\ \mathrm{X} & \mathrm{X} & \mathrm{X}\end{array}$

$\begin{array}{ll}X & X \\ X & X \\ X & X \\ X & X \\ X & X \\ X & X\end{array}$

$\begin{array}{ll}X & X \\ X & X \\ X & X \\ X & X \\ X & X \\ X & X\end{array}$

$\begin{array}{ll}\mathrm{X} & \mathrm{X} \\ \mathrm{X} & \mathrm{X} \\ \mathrm{X} & \mathrm{X} \\ \mathrm{X} & \mathrm{X} \\ \mathrm{X} & \mathrm{X} \\ \mathrm{X} & \mathrm{X}\end{array}$

$\mathrm{X}$
$\mathrm{X}$
$\mathrm{X}$
$\mathrm{X}$
$\mathrm{X}$
$\mathrm{X}$

Notes: The data is from the 1998 to 2010 EU-LFS, but restricted to the years 1998, 2003, 2008 and 2010. The sample is limited to individuals between the ages 23-57. The unit of observation is a country-occupation-year. The number of observations is 797 for all regressions (11 countries and 20 industries). We weight all the regressions using regression weights that are constructed based on the total number of individuals in the occupation, normalized to an averaged of one for each country and year. Standard errors clustered at the country level are reported in brackets. ${ }^{* * *}$ significant at the $1 \%$ level, $* * 5 \%, * 10 \%$. 
Dep. Var: Share of College Educated Females age 2342 With Children in occupation $i$

Share of males age 25 to 54 working $\mathrm{X}+$ hours

Controlling for occupation distribution of:

No. Observations

Share of males age 25 to 54 working $50+$ hours

Share of males age 25 to 54 working 50+ hours, $\mathrm{t}+1$
A. Definitions of Overwork

$$
\mathrm{X}=41
$$

$-0.028^{* *}$

$$
\mathrm{X}=45
$$

$\mathrm{X}=50$

$\mathrm{X}=55$

[0.012]

$-0.034^{* *}$

$-0.062 * *$

$-0.037$

$[0.015$

[0.022]

[0.031]

Males

797

(1)

$-0.072 * *$

[0.024]

Males
797
Males
797

Males

797

\section{B. Leads}

(2)

(3)

$-0.081 * * \quad-0.051 * * * \quad-0.054 * *$

[0.028] [0.015]

$-0.040$

$-0.014$

[0.041]

[0.035]

Females No Females No

Controlling for occupation distribution of:

Years Excluded

$\begin{array}{cc}\text { Males } & \text { Males } \\ 2010 & 2010 \\ 576 & 576\end{array}$

Children

Children

No. Observations

576
2010

$576 \quad 576$

Notes: The data is from the 1998 to 2010 EU-LFS, but restricted to the years 1998, 2003, 2008 and 2010. The sample is restricted to individuals between the ages 23-42. The unit of observation is a country-occupation-year. All regressions include country, year, and broad occupation fixed effects and all two-way interactions. We weight all the regressions using regression weights that are constructed based on the total number of individuals in the occupation, normalized to an averaged of one for each country and year. Standard errors clustered at the country level are reported in brackets. ${ }^{* * *}$ significant at the $1 \%$ level, $* * 5 \%, * 10 \%$. 
Appendix Figure 1. Cross-country variation in the prevalence of male overwork

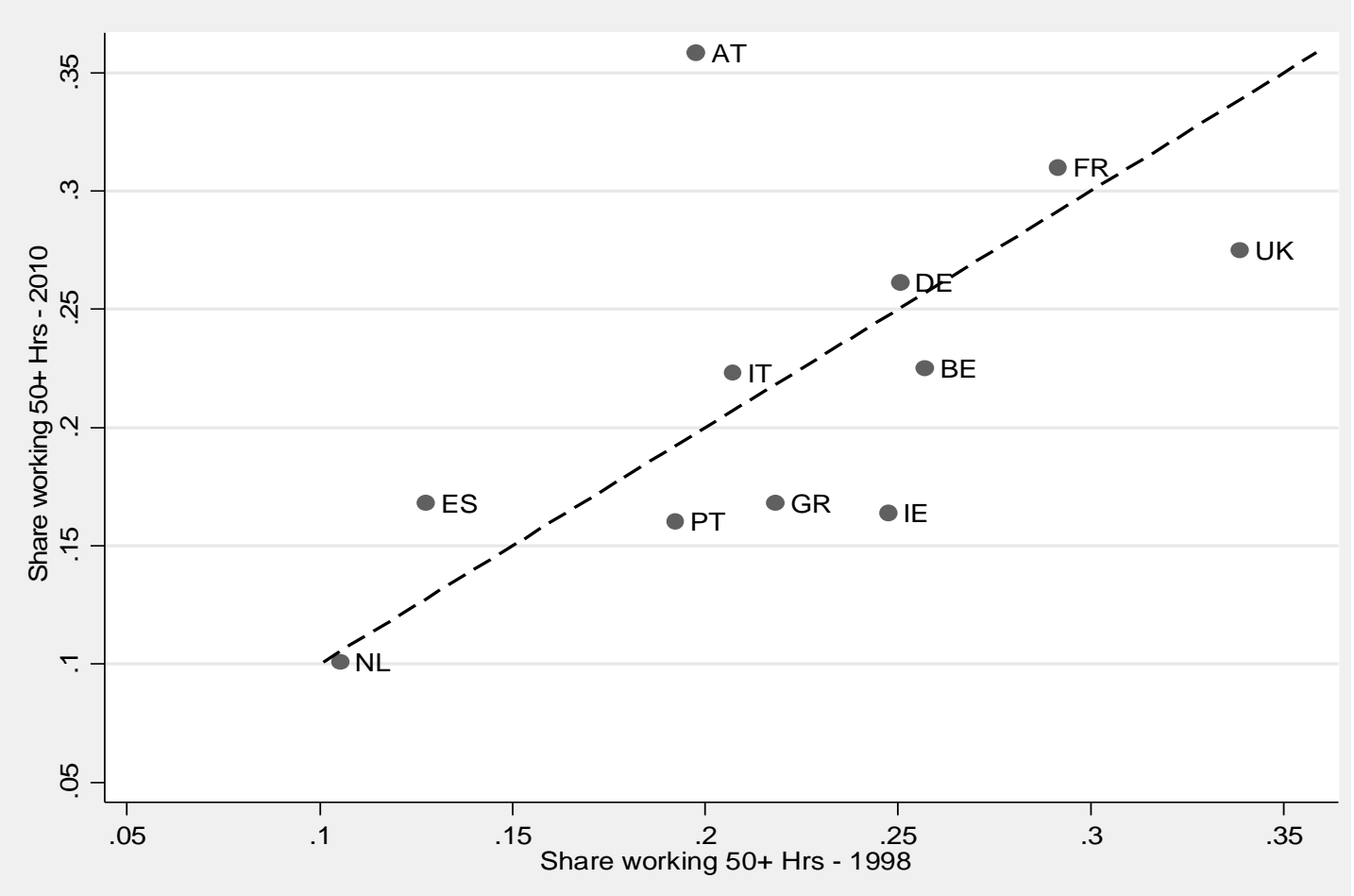

Note: Data comes from the EU-LFS. Values for Germany and Ireland in the earlier period are for 1999. Restricted to college educated males ages 23-57 working full time. 
Appendix Table 1. Average differences in daily minutes devoted to household production between female and male college educated FT workers, by day of the week

\begin{tabular}{|c|c|c|c|c|c|c|}
\hline & \multicolumn{6}{|c|}{ Average Female-Male Difference in: } \\
\hline & & Household & Total Hhld & Children & Household & Total Hhld \\
\hline & Children care & Work & Production & care & Work & Production \\
\hline Country & \multicolumn{3}{|c|}{ Weekdays } & \multicolumn{3}{|c|}{ Weekends } \\
\hline Denmark & 33 & 54 & 87 & 33 & 0 & 33 \\
\hline France & 26 & 95 & 121 & 28 & 80 & 108 \\
\hline Germany & 5 & 61 & 67 & -13 & 77 & 64 \\
\hline Italy & 10 & 109 & 119 & 24 & 169 & 193 \\
\hline Netherlands & 34 & 47 & 81 & 9 & 63 & 71 \\
\hline Norway & 72 & 53 & 125 & 55 & -11 & 44 \\
\hline Spain & 33 & 94 & 127 & 19 & 93 & 112 \\
\hline UK & 33 & 69 & 101 & 8 & 45 & 53 \\
\hline US & 27 & 41 & 68 & 9 & 60 & 69 \\
\hline
\end{tabular}

Notes: The data is from the 1998-2009 Multi-National Time-Use Survey (MTUS). The sample is restricted to workers working at least 35 hours a week, aged 25-64, who reported living with their partner and having children. 
Appendix Table 2. List of occupations included in US analysis

\begin{tabular}{|c|c|c|c|}
\hline \multicolumn{2}{|c|}{ occ1990dd Occupation Name } & \multicolumn{2}{|c|}{ occ1990dd Occupation Name } \\
\hline 4 & Chief executives, public administrators, and legislators & 156 & Primary school teachers \\
\hline 7 & Financial managers & 157 & Secondary school teachers \\
\hline 8 & Human resources and labor relations managers & 158 & Special education teachers \\
\hline 13 & Managers and specialists in marketing, advert., PR & 163 & Vocational and educational counselors \\
\hline 14 & Managers in education and related fields & 164 & Librarians \\
\hline 15 & Managers of medicine and health occupations & 165 & Archivists and curators \\
\hline 18 & Managers of properties and real estate & 166 & Economists, market and survey researchers \\
\hline 19 & Funeral directors & 167 & Psychologists \\
\hline 23 & Accountants and auditors & 173 & Urban and regional planners \\
\hline 24 & Insurance underwriters & 174 & Social workers \\
\hline 25 & Other financial specialists & 176 & Clergy and religious workers \\
\hline 26 & Management analysts & 177 & Welfare service workers \\
\hline 27 & Personnel, HR, training, and labor rel. specialists & 178 & Lawyers and judges \\
\hline 28 & Purchasing agents and buyers of farm products & 183 & Writers and authors \\
\hline 29 & Buyers, wholesale and retail trade & 184 & Technical writers \\
\hline 34 & Business and promotion agents & 185 & Designers \\
\hline 35 & Construction inspectors & 186 & Musicians and composers \\
\hline 36 & Inspectors and compliance officers, outside & 187 & Actors, directors, and producers \\
\hline 37 & Management support occupations & 188 & Painters, sculptors, craft-artists, and print-makers \\
\hline 43 & Architects & 189 & Photographers \\
\hline 44 & Aerospace engineers & 194 & Art/entertainment performers and related occs \\
\hline 45 & Metallurgical and materials engineers & 195 & Editors and reporters \\
\hline 47 & Petroleum, mining, and geological engineers & 198 & Announcers \\
\hline 48 & Chemical engineers & 199 & Athletes, sports instructors, and officials \\
\hline 53 & Civil engineers & 203 & Clinical laboratory technologies and technicians \\
\hline 55 & Electrical engineers & 206 & Radiologic technologists and technicians \\
\hline 56 & Industrial engineers & 207 & Licensed practical nurses \\
\hline 57 & Mechanical engineers & 214 & Engineering technicians \\
\hline 64 & Computer systems analysts and computer scientists & 217 & Drafters \\
\hline 65 & Operations and systems researchers and analysts & 218 & Surveryors, cartographers, mapping scientists/techs \\
\hline 66 & Actuaries & 223 & Biological technicians \\
\hline 68 & Mathematicians and statisticians & 224 & Chemical technicians \\
\hline 69 & Physicists and astronomists & 225 & Other science technicians \\
\hline 73 & Chemists & 226 & Airplane pilots and navigators \\
\hline 74 & Atmospheric and space scientists & 227 & Air traffic controllers \\
\hline 75 & Geologists & 228 & Broadcast equipment operators \\
\hline 77 & Agricultural and food scientists & 229 & Computer software developers \\
\hline 78 & Biological scientists & 234 & Legal assistants and paralegals \\
\hline 79 & Foresters and conservation scientists & 243 & Sales supervisors and proprietors \\
\hline 83 & Medical scientists & 253 & Insurance sales occupations \\
\hline 84 & Physicians & 254 & Real estate sales occupations \\
\hline 85 & Dentists & 255 & Financial service sales occupations \\
\hline 86 & Veterinarians & 256 & Advertising and related sales jobs \\
\hline 87 & Optometrists & 258 & Sales engineers \\
\hline 89 & Other health and therapy occupations & 275 & Retail salespersons and sales clerks \\
\hline 95 & Registered Nurses & 276 & Cashiers \\
\hline 96 & Pharmacists & 277 & Door-to-door sales, street sales, and news vendors \\
\hline 97 & Dieticians and nutritionists & 303 & Office supervisors \\
\hline 98 & Respiratory therapists & 308 & Computer and peripheral equipment operators \\
\hline 103 & Physical therapists & 313 & Secretaries and stenographers \\
\hline 104 & Speech therapists & 315 & Typists \\
\hline 106 & Physicians' assistants & 316 & Interviewers, enumerators, and surveyors \\
\hline 154 & Subject instructors, college & 317 & Hotel clerks \\
\hline 155 & Kindergarten and earlier school teachers & 318 & Transportation ticket and reservation agents \\
\hline
\end{tabular}


Appendix Table 2. List of occupations included in US analysis (continuation)

\begin{tabular}{|c|c|c|c|}
\hline occ1990dd & Occupation Name & occ1990dd & Occupation Name \\
\hline 319 & Receptionists and other information clerks & 479 & Farm workers, incl. nursery farming \\
\hline 326 & Correspondence and order clerks & 496 & Timber, logging, and forestry workers \\
\hline 328 & Human resources clerks, excl payroll and timekeeping & 503 & Supervisors of mechanics and repairers \\
\hline 329 & Library assistants & 505 & Automobile mechanics and repairers \\
\hline 335 & File clerks & 508 & Aircraft mechanics \\
\hline 336 & Records clerks & 516 & Heavy equipement and farm equipment mechanics \\
\hline 337 & Bookkeepers and accounting and auditing clerks & 518 & Industrial machinery repairers \\
\hline 338 & Payroll and timekeeping clerks & 523 & Repairers of industrial electrical equipment \\
\hline 344 & Billing clerks and related financial records processing & 525 & Repairers of data processing equipment \\
\hline 348 & Telephone operators & 527 & Telecom and line installers and repairers \\
\hline 354 & Postal clerks, exluding mail carriers & 534 & Heating, air conditioning, and refrigeration mechanics \\
\hline 355 & Mail carriers for postal service & 535 & Precision makers, repairers, and smiths \\
\hline 356 & Mail clerks, outside of post office & 558 & Supervisors of construction work \\
\hline 357 & Messengers & 563 & Masons, tilers, and carpet installers \\
\hline 359 & Dispatchers & 567 & Carpenters \\
\hline 364 & Shipping and receiving clerks & 575 & Electricians \\
\hline 365 & Stock and inventory clerks & 579 & Painters, construction and maintenance \\
\hline 366 & Meter readers & 585 & Plumbers, pipe fitters, and steamfitters \\
\hline 368 & Weighers, measurers, and checkers & 593 & Insulation workers \\
\hline 373 & Material recording, sched., prod., plan., expediting cl. & 628 & Production supervisors or foremen \\
\hline 375 & Insurance adjusters, examiners, and investigators & 637 & Machinists \\
\hline 376 & Customer service reps, invest., adjusters, excl. insur. & 653 & Other metal and plastic workers \\
\hline 377 & Eligibility clerks for government prog., social welfare & 657 & Cabinetmakers and bench carpeters \\
\hline 378 & Bill and account collectors & 677 & Optical goods workers \\
\hline 379 & General office clerks & 678 & Dental Laboratory and medical applicance technicians \\
\hline 383 & Bank tellers & 686 & Butchers and meat cutters \\
\hline 385 & Data entry keyers & 687 & Bakers \\
\hline 386 & Statistical clerks & 694 & Water and sewage treatment plant operators \\
\hline 387 & Teacher's aides & 695 & Power Plants Operators \\
\hline 405 & Housekeepers, maids, butlers, and cleaners & 696 & Plant and system operators, stationary engineers \\
\hline 408 & Laundry and dry cleaning workers & 699 & Other plant and system operators \\
\hline 415 & Supervisors of guards & 736 & Typesetters and compositors \\
\hline 417 & Fire fighting, fire prevention, and fire inspection occs & 754 & Packers, fillers, and wrappers \\
\hline 418 & Police and detectives, public service & 756 & Mixing and blending machine operators \\
\hline 423 & Sheriffs, bailiffs, correctional institution officers & 757 & Separating, filterin, and clarifying machine operators \\
\hline 426 & Guards and police, except public service & 774 & Photographic process workers \\
\hline 433 & Supervisors of food preparation and service & 783 & Welders, solderers, and metal cutters \\
\hline 434 & Bartenders & 785 & Assemblers of electrical equipment \\
\hline 435 & Waiters and waitresses & 789 & Painting and decoration occupations \\
\hline 436 & Cooks & 799 & Production checkers, graders, and sorters in \\
\hline 444 & Miscellanious food preparation and service workers & 803 & Supervisors of motor vehicle transportation \\
\hline 447 & Health and Nursing Aids & 804 & Truck, delivery, and tractor drivers \\
\hline 448 & Supervisors of cleaning and building service & 808 & Bus drivers \\
\hline 450 & Superv. of landscaping, lawn service, groundskeeping & 809 & Taxi cab drivers and chauffeurs \\
\hline 451 & Gardeners and groundskeepers & 823 & Railroad conductors and yardmasters \\
\hline 453 & Janitors & 824 & Locomotive operators: engineers and firemen \\
\hline 458 & Hairdressers and cosmetologists & 829 & Ship crews and marine engineers \\
\hline 459 & Recreation facility attendants & 844 & Operating engineers of construction equipment \\
\hline 461 & Guides & 859 & Stevedores and misc. material moving occupations \\
\hline 466 & Recreation and fitness workers & 869 & Construction Laborers \\
\hline 468 & Child care workers & 885 & Garage and service station related occupations \\
\hline 471 & Public transportation attendants and inspectors & 887 & Vehicle washers and equipment cleaners \\
\hline 472 & Animal caretakers, except farm & 888 & Packers and packagers by hand \\
\hline 475 & Farm managers & & \\
\hline
\end{tabular}




\begin{tabular}{lcccc}
\hline & 1980 & 1990 & 2000 & 2010 \\
Share of Males Working 50+ & 0.227 & 0.289 & 0.325 & 0.295 \\
hrs a week & $(0.086)$ & $(0.085)$ & $(0.105)$ & $(0.103)$ \\
Share of Married Females With & 0.091 & 0.101 & 0.075 & 0.059 \\
Children Aged 25-54 & $(0.099)$ & $(0.114)$ & $(0.079)$ & $(0.060)$ \\
Share of Males Aged 25-54 & 0.023 & 0.020 & 0.018 & 0.018 \\
& $(0.020)$ & $(0.018)$ & $(0.015)$ & $(0.014)$ \\
Log(Wage Females) & 2.367 & 2.537 & 2.578 & 2.590 \\
& $(0.164)$ & $(0.187)$ & $(0.173)$ & $(0.198)$ \\
Std. Log(Wage females) & 0.377 & 0.415 & 0.439 & 0.432 \\
& $(0.053)$ & $(0.060)$ & $(0.069)$ & $(0.075)$ \\
Log(Wage Males) & 2.559 & 2.691 & 2.682 & 2.695 \\
& $(0.147)$ & $(0.165)$ & $(0.185)$ & $(0.218)$ \\
Std. Log(Wage Males) & 0.423 & 0.466 & 0.490 & 0.474 \\
& $(0.065)$ & $(0.081)$ & $(0.085)$ & $(0.097)$ \\
No. of Occupations & 215 & 215 & 215 & 215 \\
\hline
\end{tabular}

Notes: Data comes from the 1980-2000 Census and 2012 3-year ACS. The data is at the occupation level. The summary statistics refer to college educated workers aged 25-54. Observations weighted by cell size. 
Appendix Table 4. Relationship between the prevalence of overwork and gender differences in occupational distribution by decade

\begin{tabular}{|c|c|c|c|c|c|c|c|c|}
\hline & \multicolumn{8}{|c|}{ Female - Male Difference in Employment Share } \\
\hline & 2010 & 2000 & 1990 & 1980 & 2010 & 2000 & 1990 & 1980 \\
\hline & (1) & $(2)$ & (3) & (4) & (5) & (6) & (7) & (8) \\
\hline $\begin{array}{l}\text { Share of males } \\
\text { working } 50+\text { hours }\end{array}$ & $\begin{array}{c}-0.057 * * * \\
{[0.017]}\end{array}$ & $\begin{array}{c}-0.081 * * * \\
{[0.025]}\end{array}$ & $\begin{array}{c}-0.147 * * \\
{[0.070]}\end{array}$ & $\begin{array}{c}-0.107 * \\
{[0.064]}\end{array}$ & $\begin{array}{c}-0.028 * * * \\
{[0.007]}\end{array}$ & $\begin{array}{c}-0.035 * * * \\
{[0.007]}\end{array}$ & $\begin{array}{c}-0.038 * * * \\
{[0.009]}\end{array}$ & $\begin{array}{c}-0.028 * * \\
{[0.012]}\end{array}$ \\
\hline Excluded occs. & none & none & none & none & & i Sch Teacl & lers \& Nurs & \\
\hline Observations & 215 & 215 & 215 & 215 & 213 & 213 & 213 & 213 \\
\hline R-squared & 0.063 & 0.085 & 0.100 & 0.030 & 0.242 & 0.352 & 0.275 & 0.069 \\
\hline
\end{tabular}

Notes: The data is from the 1980 to 2000 US Census and the 2012 3-year aggregate ACS. The unit of observation is an occupation. The outcome is the female - male difference in the share of college-educated individuals age 25 to 54 employed full-time in each occupation. The independent variable is the share of males age 25 to 54 who reported working 50 or more hours per week in each occupation. The first four columns include all 215 consistently defined occupations. Columns (5) to (8) exclude primary school teachers and registered nurses. All regressions are weighted by the number of college-educated females age 25 to 54 in each occupation. Robust standard errors are reported in brackets.***significant at the $1 \%$ level, $* * 5 \%, * 10 \%$. 
Share of males age 25 to 54 working $50+$ hours

Share of males of the same age working in occupation $i$ :

Dep. Var: Share of College Educated Married Females age 25-40 with Children working in occupation $i$

$\begin{array}{llll}1980 & 1990 & 2000 & 2010\end{array}$

(1)

(2)

(3)

$-0.214 * *$ $-0.244^{* *}$ $-0.149 *$ $-0.144^{* *}$

[0.083]

[0.081] [0.070]

$\begin{array}{cccc}4.965 * * * & 6.891 * * * & 4.169 * * * & 4.052 * * * \\ {[0.512]} & {[1.112]} & {[0.622]} & {[0.458]}\end{array}$

Average and standard deviation of log male and female wages

Observations

X

215

0.886

\section{X}

215

0.827
X

215

0.828
X

215 0.886

Notes: The data is from the 1980 to 2000 US Census and the 2012 3-year aggregate ACS. The unit of observation is an occupation. The average and standard deviation of log female and male wages are computed for full-time workers age 25 to 54. The regressions are weighted by the number of workers (as defined by the outcome) in the occupation in 1980 . Standard errors clustered at the occupation level are reported in brackets. ${ }^{* * *}$ significant at the $1 \%$ level, $* * 5 \%,{ }^{*} 10 \%$. 
Appendix Table 6: Occupational classification for the country-cccupation-year panel

\begin{tabular}{|c|c|c|}
\hline \multicolumn{2}{|r|}{ Occupation in the EU-LFS } & \multirow[b]{2}{*}{ Broad Occupation Group } \\
\hline ISCO-88 & Name & \\
\hline 110 & Legislators and senior officials, nos & Legislators and Managers \\
\hline 111 & Legislators & Legislators and Managers \\
\hline 114 & Senior officials of special-interest organisations & Legislators and Managers \\
\hline 120 & Corporate managers, nos & Legislators and Managers \\
\hline 121 & Directors and chief executives & Legislators and Managers \\
\hline 122 & Production and operations managers & Legislators and Managers \\
\hline 123 & Other specialist managers & Legislators and Managers \\
\hline 130 & Managers of small enterprises, nos & Legislators and Managers \\
\hline 131 & Managers of small enterprises & Legislators and Managers \\
\hline 211 & Physicists, chemists and related profss. & Natural and Life Sciences, Math and Computing profss. \\
\hline 212 & Mathematicians, statisticians and related profss. & Natural and Life Sciences, Math and Computing profss. \\
\hline 213 & Computing profss. & Natural and Life Sciences, Math and Computing profss. \\
\hline 214 & Architects, engineers and related profss. & Architects and engineers \\
\hline 221 & Life science profss. & Natural and Life Sciences, Math and Computing profss. \\
\hline 222 & Health profss. (except nursing) & Health profss. \\
\hline 223 & Nursing and midwifery profss. & Health profss. \\
\hline 231 & College, university and higher education teaching profss. & Educators \\
\hline 232 & Secondary education teaching profss. & Educators \\
\hline 233 & Primary and pre-primary education teaching profss. & Educators \\
\hline 234 & Special education teaching profss. & Educators \\
\hline 235 & Other teaching profss. & Educators \\
\hline 241 & Business profss. & Business profss. (Accountants, HR, etc) \\
\hline 242 & Legal profss. & Legal profss. \\
\hline 243 & Archivists, librarians and related information profss. & Educators \\
\hline 244 & Social science and related profss. & Social Scientists \\
\hline 245 & Writers and creative or performing artists & Writers and Artists \\
\hline 246 & Religious profss. & Religious/social workers \\
\hline 247 & Public service administrative profss. & Public Administration profss. \\
\hline 311 & Physical and engineering science technicians & Associate profss. excluding Business \\
\hline 312 & Computer associate profss. & Associate profss. excluding Business \\
\hline 313 & Optical and electronic equipment operators & Associate profss. excluding Business \\
\hline 314 & Ship and aircraft controllers and technicians & Associate profss. excluding Business \\
\hline 315 & Safety and quality inspectors & Associate profss. excluding Business \\
\hline 321 & Life science technicians and related associate professional & Associate profss. excluding Business \\
\hline 322 & Health associate profss. (except nursing) & Associate profss. excluding Business \\
\hline 323 & Nursing and midwifery associate profss. & Associate profss. excluding Business \\
\hline 331 & Primary education teaching associate profss. & Associate profss. excluding Business \\
\hline 332 & Pre-primary education teaching associate profss. & Associate profss. excluding Business \\
\hline 333 & Special education teaching associate profss. & Associate profss. excluding Business \\
\hline 334 & Other teaching associate profss. & Associate profss. excluding Business \\
\hline 341 & Finance and sales associate profss. & Business and Finance Associate profss. \\
\hline
\end{tabular}


Appendix Table 6: Occupational classification for the country-cccupation-year panel (continuation)

\begin{tabular}{|c|c|c|}
\hline \multicolumn{2}{|r|}{ Occupation in the EU-LFS } & \multirow[b]{2}{*}{ Broad Occupation Group } \\
\hline ISCO-88 & Name & \\
\hline 342 & Business services agents and trade brokers & Business and Finance Associate profss. \\
\hline 343 & Administrative associate profss. & Administrative Associate profss. \\
\hline 344 & Customs, tax and related government associate profss. & Administrative Associate profss. \\
\hline 345 & Police inspectors and detectives & Administrative Associate profss. \\
\hline 346 & Social work associate profss. & Religious/social workers \\
\hline 347 & Artistic, entertainment and sports associate profss. & Writers and Artists \\
\hline 348 & Religious associate profss. & Religious/social workers \\
\hline 411 & Secretaries and keyboard-operating clerks & Office clerks \\
\hline 412 & Numerical clerks & Office clerks \\
\hline 413 & Material-recording and transport clerks & Office clerks \\
\hline 414 & Library, mail and related clerks & Office clerks \\
\hline 419 & Other office clerks & Office clerks \\
\hline 421 & Cashiers, tellers and related clerks & Cashiers, tellers, client information clerks \\
\hline 422 & Client information clerks & Cashiers, tellers, client information clerks \\
\hline 511 & Travel attendants and related workers & Service Workers (restaurants, housholds, personal care) \\
\hline 512 & Housekeeping and restaurant services workers & Service Workers (restaurants, housholds, personal care) \\
\hline 513 & Personal care and related workers & Service Workers (restaurants, housholds, personal care) \\
\hline 514 & Other personal services workers & Service Workers (restaurants, housholds, personal care) \\
\hline 516 & Protective services workers & Service Workers (restaurants, housholds, personal care) \\
\hline 521 & Fashion and other models & Writers and Artists \\
\hline 522 & Shop, stall and market salespersons and demonstrators & Market salespersons \\
\hline 611 & Market gardeners and crop growers & Precisions production, operators, craft and repair occs. \\
\hline 612 & Animal producers and related workers & Precisions production, operators, craft and repair occs. \\
\hline 613 & Crop and animal producers & Precisions production, operators, craft and repair occs. \\
\hline 614 & Forestry and related workers & Precisions production, operators, craft and repair occs. \\
\hline 615 & Fishery workers, hunters and trappers & Precisions production, operators, craft and repair occs. \\
\hline 710 & Extraction and building trades workers, nos & Precisions production, operators, craft and repair occs. \\
\hline 711 & Miners, shotfirers, stone cutters and carvers & Precisions production, operators, craft and repair occs. \\
\hline 712 & Building frame and related trades workers & Precisions production, operators, craft and repair occs. \\
\hline 713 & Building finishers and related trades workers & Precisions production, operators, craft and repair occs. \\
\hline 714 & Painters, building structure cleaners and related trades workers & Precisions production, operators, craft and repair occs. \\
\hline 721 & , and related trades workers & Precisions production, operators, craft and repair occs. \\
\hline 722 & Blacksmiths, tool-makers and related trades workers & Precisions production, operators, craft and repair occs. \\
\hline 723 & Machinery mechanics and fitters & Precisions production, operators, craft and repair occs. \\
\hline 724 & Electrical and electronic equipment mechanics and fitters & Precisions production, operators, craft and repair occs. \\
\hline 730 & Precision, handicraft, printing and related trades workers, nos & Precisions production, operators, craft and repair occs. \\
\hline 731 & Precision workers in metal and related materials & Precisions production, operators, craft and repair occs. \\
\hline 732 & Potters, glass-makers and related trades workers & Precisions production, operators, craft and repair occs. \\
\hline 733 & Handicraft workers in wood, textile, leather and related materials & Precisions production, operators, craft and repair occs. \\
\hline
\end{tabular}


Appendix Table 6: Occupational classification for the country-cccupation-year panel (continuation)

\begin{tabular}{|c|c|c|}
\hline \multicolumn{2}{|r|}{ Occupation in the EU-LFS } & \multirow[b]{2}{*}{ Broad Occupation Group } \\
\hline ISCO-88 & Name & \\
\hline 734 & Craft printing and related trades workers & Precisions production, operators, craft and repair occs. \\
\hline 740 & Other craft and related trades workers, nos & Precisions production, operators, craft and repair occs. \\
\hline 741 & Food processing and related trades workers & Precisions production, operators, craft and repair occs. \\
\hline 742 & Wood treaters, cabinet-makers and related trades workers & Precisions production, operators, craft and repair occs. \\
\hline 743 & Textile, garment and related trades workers & Precisions production, operators, craft and repair occs. \\
\hline 744 & Pelt, leather and shoemaking trades workers & Precisions production, operators, craft and repair occs. \\
\hline 810 & Stationary plant and related operators, nos & Precisions production, operators, craft and repair occs. \\
\hline 811 & Mining and mineral-processing-plant operators & Precisions production, operators, craft and repair occs. \\
\hline 812 & Metal-processing plant operators & Precisions production, operators, craft and repair occs. \\
\hline 813 & Glass, ceramics and related plant operators & Precisions production, operators, craft and repair occs. \\
\hline 814 & Wood-processing- and papermaking-plant operators & Precisions production, operators, craft and repair occs. \\
\hline 815 & Chemical-processing-plant operators & Precisions production, operators, craft and repair occs. \\
\hline 816 & Power-production and related plant operators & Precisions production, operators, craft and repair occs. \\
\hline 817 & Industrial robot operators & Precisions production, operators, craft and repair occs. \\
\hline 820 & Machine operators and assemblers, nos & Precisions production, operators, craft and repair occs. \\
\hline 821 & Metal- and mineral-products machine operators & Precisions production, operators, craft and repair occs. \\
\hline 822 & Chemical-products machine operators & Precisions production, operators, craft and repair occs. \\
\hline 823 & Rubber- and plastic-products machine operators & Precisions production, operators, craft and repair occs. \\
\hline 824 & Wood-products machine operators & Precisions production, operators, craft and repair occs. \\
\hline 825 & Printing-, binding- and paper-products machine operators & Precisions production, operators, craft and repair occs. \\
\hline 826 & Textile-, fur- and leather-products machine operators & Precisions production, operators, craft and repair occs. \\
\hline 827 & Food and related products machine operators & Precisions production, operators, craft and repair occs. \\
\hline 828 & Assemblers & Precisions production, operators, craft and repair occs. \\
\hline 829 & Other machine operators not elsewhere classified & Precisions production, operators, craft and repair occs. \\
\hline 830 & Drivers and mobile plant operators, nos & Precisions production, operators, craft and repair occs. \\
\hline 831 & Locomotive engine drivers and related workers & Precisions production, operators, craft and repair occs. \\
\hline 832 & Motor vehicle drivers & Precisions production, operators, craft and repair occs. \\
\hline 833 & Agricultural and other mobile plant operators & Precisions production, operators, craft and repair occs. \\
\hline 834 & Ships' deck crews and related workers & Precisions production, operators, craft and repair occs. \\
\hline 910 & Sales and services elementary occs., nos & Laborers/elementary occs. \\
\hline 911 & Street vendors and related workers & Laborers/elementary occs. \\
\hline 912 & Shoe cleaning and other street services elementary occs. & Laborers/elementary occs. \\
\hline 913 & Domestic and related helpers, cleaners and launderers & Laborers/elementary occs. \\
\hline 914 & Building caretakers, window and related cleaners & Laborers/elementary occs. \\
\hline 915 & Messengers, porters, doorkeepers and related workers & Laborers/elementary occs. \\
\hline 916 & Garbage collectors and related labourers & Laborers/elementary occs. \\
\hline 921 & Agricultural, fishery and related labourers & Laborers/elementary occs. \\
\hline 930 & Labourers in mining, cons., manufacturing and transport, nos & Laborers/elementary occs. \\
\hline 931 & Mining and construction labourers & Laborers/elementary occs. \\
\hline 932 & Manufacturing labourers & Laborers/elementary occs. \\
\hline 933 & Transport labourers and freight handlers & Laborers/elementary occs. \\
\hline
\end{tabular}

